\title{
Az Intim Kötődés Mérése (IBM-HU) kérdőív pszichometriai jellemzóinek bemutatása
}

\author{
HADHÁZI ÉVA - TAKÁCS SZABOLCS² \\ ${ }^{1}$ Károli Gáspár Református Egyetem, Pszichológiai Intézet, \\ Fejlődéslélektani Tanszék, Budapest \\ ${ }^{2}$ Károli Gáspár Református Egyetem, Pszichológiai Intézet, Általános Lélektani \\ és Módszertani Tanszék, Budapest
}

(Beérkezett: 2018. november 29., elfogadva: 2019. április 26.)

Elméleti háttér: Az Intim Kötődés Mérése (Intimate Bond Measurement; IBM) kérdőív, az intimitás két fő konstruktumának, a gondoskodás és a kontroll dimenziójának a meghatározására, mérésére alkalmas, nemzetközi kutatásokban főleg a párkapcsolati intimitás mérésére használt eszköz. Cél: Tanulmányunkban bemutatjuk a kérdőív pszichometriai jellemzőit magyar populáción. Módszer: Önbeszámolós kérdőíves, keresztmetszeti vizsgálatban 1318 fő (250 férfi, 1068 nó; átlagéletkor 34,77 év, SD = 10,91 év) a demográfiai adatok és IBM mellett kitöltötte a Kapcsolati Elégedettség Skálát, a Közvetlen Kapcsolatok Élményei Kérdőívet, a Szülői Bánásmód Kérdőívet, a Vonásszorongás skálát, a Zung-féle Önértékelő Depresszió Skálát és a MOS Társas Támasz kérdőívet. Eredmények: A megerősító és feltáró faktoranalízisek során ugyanaz a faktorstruktúra rajzolódott ki, mint amit a nemzetközi szakirodalom is igazolt. A Cronbach-a értékei megfelelően magasak (Gondoskodás skála: 0,94 ; Kontroll skála: 0,91$)$, és a skálák negatívan korreláltak $(r=-0,58$; $p<0,01)$. Az intimitás mértéke függetlennek bizonyult a szociodemográfiai tényezőktől (nem, iskolázottság, lakóhely, jövedelmi helyzet, családi állapot, gyermekek megléte és száma). A saját bevallás szerint krónikus betegségben szenvedők és lelki okokból kezelésben részesültek megkülönböztetésre kerültek a sine morbo csoporttól és a Gondoskodás skála értékeiben alatta maradtak az ilyen jellemzőkkel nem rendelkezőktől, míg a Kontroll skála értékei a lelki okokból kezelésben részesülteknél bizonyultak szignifikánsan magasabbnak. Az intimitás egyéb tényezókkel való együttjárását csak ott vettük figyelembe, ahol a korrelációs együttható elérte a 0,3 -as szintet. A párkapcsolattal való elégedettség erős, pozitív irányú együttjárást mutatott a gondoskodással, negatívat a kontrollal. A gondoskodás negatívan, míg a kontroll pozitívan korrelált a felnőtt párkapcsolati kötődés elkerülés és szorongás alskálájával. A szülői bánásmódból az apai korlátozás emelkedik ki, a lelki problémák miatt kezeltek csoportjánál: minél korlátozóbbnak élték meg apjukat, annál kevésbé gondoskodónak és annál inkább kontrollálónak észlelik a párjukat. A depresszióval és a vonásszorongással negatív összefüggést jelzett a gondoskodás észlelése, bár nem mindenhol érte el a releváns mértéket. A kontroll észlelése csak a krónikus betegséggel küzdőknél járt együtt a depresszióval és a vonásszorongással. A társas támasz

\footnotetext{
* Levelező szerző: dr. Hadházi Éva, Károli Gáspár Református Egyetem, Bölcsészettudományi Kar, 1037 Budapest, Bécsi út 324. V. ép. E-mail: ahadhazi@enternet.hu
} 
mindhárom dimenziójának pozitív együttjárását találtuk a gondoskodással, a kontrollal is következetesen negatív irányú együttjárást tapasztaltunk, de ezek erőssége meglehetősen változatosnak bizonyult. Következtetés: az IBM-HU az intimitás gondoskodás és kontroll dimenzióinak megbízható és érvényes mérőeszközének tekinthető.

Kulcsszavak: intimitás, intim kötődés mérése, IBM-HU, megerősítő és feltáró faktorelemzés, megbízhatóság, érvényesség

\section{Bevezetés}

\subsection{Az intimitás fogalma és pszichológiai megközelítései}

Az intim szó, mint melléknév, jelentése a magyar értelmező szótár szerint „olyan, ami valakinek csak a legszúkebb környezetére tartozik, legbelső, legrejtettebb gondolataira, érzelmeire vonatkozik, s ami nem a nyilvánosság, nem a nagyvilág elé való; bizalmas, meghitt, bensőséges, valakihez közel álló (személy)" (Bárczi \& Országh, 1959-1962, 3250A).

A pszichológiai nomenklatúrában a fogalom meghatározása nem egységes, a kutatók más-más definiálási szempontokat tartanak szem előtt, tekintettel az intimitás megélésének szubjektív voltára, az intimitás megnyilvánulásainak és az átélt élményeknek a sokszínúségére. Az alábbiakban néhány meghatározási szempontot ismertetünk a teljesség igénye nélkül (a téma részletes bemutatását ld. Urbán, 1994).

A kutatások fókusza a párkapcsolati közelség szintjének a figyelembevételére (Heller \& Wood, 1998), az én élmények és érzések megosztására, valamint a társ által történő érvényesítés folyamatára (Clark \& Reis, 1988), a fontos érzelmek, gondolatok és cselekedetek megosztása révén megteremthető intimitásra egyaránt kiterjed (Hatfield, 1988). Számos intimitásjellemzőt azonosítottak, például az önfeltárulkozás és a partner válaszkészsége - mint tapasztalat - bizonyultak a közelség és a kapcsolódási készség meghatározóinak (Reis \& Shaver, 1988). Register és Henley (1992) szerint, a nonverbális kommunikáció, jelenlét, idő, kötődés, test, sorsszerúség/ meglepetés és átalakulás az intimitás összetevői. Braiker és Kelley (1979, id. Pritchett és mtsai, 2011) a feleség szemszögéből az intim kapcsolatok négy faktorát határozta meg: a szerelem és ambivalencia érzése a férj irányában, milyen mértékben érzi azt a feleség, hogy ők megkísérlik fenntartani a házasságukat, illetve, hogy mennyi konfliktus jellemzi a férjével való interakcióikat. Snell, Sebby és Wenta (2002) 12 dimenziót azonosítottak, amelyek mentén leírhatók az egyének intim kapcsolódási stílusai (intimate relationship styles), aszerint, hogy milyen lelki tendenciák függnek össze az intimitással („kapcsolat értékelése”, , "kapcsolati belevonódás”, „,belső kapcsolati kontroll”, ,kapcsolati tudatosság”, "kapcsolati szorongás”, ,kapcsolati 
asszertivitás”, ,"kapcsolati depresszió”, , „külső kapcsolati kontroll”, ,,kapcsolati monitorozás", "félelem a kapcsolattól", ,kapcsolati elégedettség”, „kapcsolati motiváció"). Ez a megközelítés azért is lehet jelentős, mert további kutatások összefüggéseket találtak e változók és a stresszkeltó eseményekre adott reakció (Snell, Sebby, \& Wenta, 2002), a kapcsolódási stílus (Mikulincer, Florian, Cowan, \& Cowan, 2002) és a családi jellemzők (Kikuchi \& Snell, 2002) között. A „kapcsolati elégedettség” mediátor tényezőnek bizonyult a biztonságos kötődés és a depresszív tünetek megjelenése közötti negatív összefüggésben, míg a „kapcsolati monitorozás” az elárasztott kötődés és depresszív tünetek közötti pozitív kapcsolatot mediálja (Altin \& Terzi, 2010).

Mivel az objektivitást nélkülöző fenomenológiai tapasztalatról van szó, Talmadge és Dabbs (1990) meglátása, hogy a megfigyelhetó aspektusokra érdemes koncentrálni, így az egyetértés gyakoriságára, a hangszínre, valamint a közös tevékenységek számára.

A meghatározások egy része kiemeli a személy önismeretének a fontosságát. Malone és Malone (1987, id. Patrick, Sells, Giordano, \& Tollerud, 2007) úgy vélik, hogy el kell érni a személyiségfejlődésnek egy bizonyos szintjét, hogy képessé váljunk a másikkal való intimitásra. Demunck és Korotayev (2007) szerint az intimitás megkövetel bizonyos attribútumokat, így a self autonómiáját és társadalmi státusztól való elkülönülését, a részvevők relatív egyenlőségét és nem agresszív, szeretetre méltó viszonyulását, önkéntességet, hogy a választott fél sajátos személyes tulajdonságai alapján legyen egyedi, legalábbis nem könnyen helyettesíthetó, autonóm szelf.

Az intimitást számos szerző szükségletnek tekinti, s mint ilyent, a valakihez való tartozás igényeként definiálják, olyan késztetésként, amely pozitív, stabil interperszonális kapcsolat kialakítására és fenntartására indít. Lavigne Vallerand és Crevier-Braud (2011) két alapvetó beállítódást különböztetnek meg: az egyik a növekedés, vagyis az interperszonális aktualizáció, a másik a hiánycsökkentés, azaz az interperszonális deficit csökkentésére irányul. A növekedés magasabb, a deficitcsökkentés pedig alacsonyabb intra- és interperszonális pszichológiai múködésekkel hozható kapcsolatba.

Wilhelm és Parker (1988) is a szükséglet megközelítését alkalmazzák az intimitás meghatározására, egyetértésben Clinebell és Clinebell (1970) felfogásával, miszerint az intimitás a kölcsönös szükségletek kielégítéseként határozható meg. Az intimitást egy kétirányú fogalomnak tekintik, amely a saját szükségleteink és a másiktól kapott alkotórészek mentén definiálható. Az intim kapcsolatokat meghatározó összetevőkként a gondoskodást és a kontrollt azonosították, hangsúlyozva, hogy e két komponens nem jelenti magát az intimitást.

A teljesség igénye nélkül felvillantott meghatározási szempontokból is kiviláglik, hogy valószínúsíthetően pont az összetevők sokszínúségének 
köszönhetően, meglehetős definíciós bizonytalanságokkal kell számolni. Ugyanakkor megállapítható, hogy a közelség és kapcsolódás érzése olyan, a partnerek kommunikációja révén kialakuló és folyamatosan fejlődő tényezők (Laurenceau, Barett Feldman, \& Pietromonaco, 1998), amelyek az intimitást a társas támasz egy kitüntetett szegmensévé teszik. Fontosságának elismerése mellett be kell látnunk, hogy nehezen megjósolható, hogy ki milyen mértékben tud intim kapcsolatokat létrehozni, fenntartani. Az intimitás mérésére tett kísérletek pont ennek a folyamatnak a jobb megismerését kívánják segíteni.

\subsection{Az intimitás mérése -}

Az Intim Kötődés Mérése (Intimate Bond Measurment, IBM) kialakításának háttere és pszichometriai jellemzői

A kutatók már az 1950-es évektől különféle módszerekkel kísérleteztek, hogy megragadják az intimitás minőségét. Wilhelm és Parker (1988) áttekintését alapul véve, íme néhány példa a korai kérdőíves, illetve interjús vizsgálatokra. Már az ötvenes évektől mérték a házassági összeillést (Locke-Wallace Skála, 1959; id. Wilhelm \& Parker, 1988; Spanier, 1976), majd a nem jól múködő házasság és a neuroticizmus összefüggéseit (Pond, Ryle, \& Hamilton, 1963), a házastársak által adott és kapott érzelmek, a dominancia és alávetettség mintázatait (Ryle, 1966). Félig strukturált interjúval a társas támaszt vizsgálták, majd különbséget tettek a házastársi és egyéb bizalmas viszonyok között (Brown \& Harris, 1978; Costello, 1982; Henderson, Byrne, \& Duncan-Jones, 1981; O'Connor \& Brown, 1984). Közvetlenül az intimitás mérésére két eszközt dolgoztak ki, az 5 komponenst vizsgáló Personal Assessment of Intimacy in Relationships (Shaefer \& Olson, 1981) és a 8 alskálát tartalmazó Waring Intimacy Questionnaire (Warring \& Reddon, 1983) kérdőívet. Ezek mindegyike előre meghatározott kulcskonstruktumait feltételezte az intimitásnak.

Wilhelm és Parker (1988) úgy döntöttek, hogy nem előre definiált konstruktumokat használnak, hanem heterogén tételek (a vonatkozó szakirodalom alapján, illetve interjúk segítségével történő) gyújtése után faktoranalízissel azonosítják az intimitást meghatározó elemeket, és egy mindkét nem számára használható, könnyen felvehető és kiszámolható önkitöltős kérdőívet hoznak létre. Így született meg az Intim Kötődés Mérése (Intimate Bond Measure) kérdőív.

A mérőeszköz 24 tétel segítségével ragadja meg, hogy a kitöltő személy milyennek észleli a partnere iránta tanúsított attitúdjeit és viselkedéses megnyilvánulásait. Az instrukció egyszerú, világos: „Ez a kérdőív a közeli kapcsolatokban megjelenő attitüdök és viselkedések listáját tartalmazza. Kérem, itél- 
je meg, milyen attitüd és viselkedésmintát mutat mostanában a partnere Önnel szemben úgy, hogy minden tétel esetében a legmegfelelöbb rubrikába tesz egy pipát." A kérdőív azt méri, hogy milyen mértékú intimitást észlelünk a párunk attitúdjei és viselkedése alapján. A válaszadás egy 4-fokú Likert-típusú skálán történik, a "tökéletesen igaz” (3), "többnyire igaz” (2), „kismértékben igaz” (1) és „egyáltalán nem igaz” (0) lehetőségek valamelyikének megjelölésével. Két skálája, a „Gondoskodás” és „Kontroll” dimenzióit tartalmazza, egyenként 12-12 tétellel. A Gondoskodás dimenzió érzelmi és fizikai gondoskodást fejez ki, melegséget, figyelmet, vonzalmat és baráti kapcsolatot. A Kontroll dimenzió dominanciát, tolakodást, kritikát, tekintélyelvú attitúdöt és viselkedést fed. A méróeszköz tételei egyirányúak. A kapott pontértékeket (tételenként 0-3-at), skálánként kell összegezni, és az elérhető maximális pontszám dimenziónként 36. A két dimenzió mindegyike homogén és egymással negatívan korrelál. Vagyis minél inkább nő a kontroll egy intim kapcsolatban, annál inkább csökken a gondoskodás.

A kérdőív reliabilitási mutatói nagyon jók. A szerző́k vizsgálati mintájában (Wilhelm \& Parker, 1988) 148 nő, 96 férfi vett részt, az átlagéletkor 39,7 év ( $\mathrm{SD}=12,8$ év) volt. A Cronbach-a értéke a Gondoskodás skála esetében 0,94 , a Kontroll skálánál 0,89 . Az átlag és szórás a Gondoskodás skálán nóknél 27,1 (8,3), férfiaknál 28,4 (8,0), a Kontroll skálán a nőknél 9,6 (8,3), a férfiaknál 11,2 (7,3). A teszt-reteszt reliabilitást 28 önkéntessel végezték (átlagéletkor 34 év, SD = 6,2 év), a két felvétel közötti idő 3 és 6 hét között változott, a korreláció nagyon magasnak bizonyult: a gondoskodás 0,89 , a kontroll 0,80 ( $p<0,001$ mindkét esetben).

A validitást strukturált interjúk segítségével ellenőrizték, ahol 33 személy esetében két szakember („,A" személye állandó volt mind a 33 embernél, „B” személye változott) egymástól függetlenül ítélte meg, egy 6-fokú skálán, a gondoskodás és kontroll mértékét a kérdéseikre adott válaszok alapján. Az inter-rater reliabilitás mérsékelt konszenzusra utal, a Gondoskodásnál 0,66, a Kontrollnál 0,70 volt ( $p<0,001$ mindkét esetben). A kitöltött kérdőívek alapján mért Gondoskodás és Kontroll értékeket korreláltatták a bírálók által adott értékeléssel, a Gondoskodás skála esetében a korrelációs együttható értéke A-val 0,68, B-vel 0,43, a Kontroll skála esetében A-val 0,74, B-vel 0,55 volt. A magasabb értékeket az A szakember konzekvens ítélkezésével és jobb kérdőív ismeretével magyarázták, ugyanakkor a nagy egyezés az interjús becslés és önkitöltős eszköz eredményei között a mérőeszköz meggyőző érvényességét támasztja alá, amit Wilhelm és Parker (1988) elóvigyázatosságból mérsékeltnek tartanak.

Mivel egy fenomenológiai eszköz kifejlesztése volt a cél, Wilhelm és Parker (1988) úgy vélték, hogy az észlelt jellemzőknek meg kell jelenniük a párkapcsolatban. Így 25, párterápiára járó párt értékeltettek a terapeutákkal a gondoskodás és kontroll megnyilvánulásaik alapján és korreláltatták a há- 
zastársak által kitöltött IBM-értékekkel. A férjek megnyilvánulásait a feleségek által észleltekkel vetették össze és fordítva. Közepes volt az együttjárás mértéke a terapeuta becslése és a házastárs észlelete között a férjek és feleségek gondoskodó és kontrolláló megnyilvánulása esetében is. E vizsgálat célja az volt, hogy ne nélkülözzék teljesen az "objektív realitást”, kapjanak némi információt az aktuális kapcsolat jellemzőiről, mert feltételezték, hogy az eltér az észleltektől. A mérsékelt erősségú összefüggés a terapeuták és párok értékelése között, némileg alátámasztja, hogy a kérdőív az aktuális jellemzőket is méri.

Wilhelm és Parker (1988) eredményei szerint sem az életkor, sem a nem, sem a szociális státusz nincs hatással az IBM kérdőíven elért értékekre. Ezek együttes hatása mindössze 1,9\% -át magyarázta a gondoskodásnak, és 3,0\%át a kontrollnak. Ezen eredmények közül az intimitás nemmel való összefüggésének hiánya a legmeglepőbb, amit a szerzők azzal magyaráztak, hogy minden olyan tétel kikerült a kérdőívből, amely nemre specifikusnak volt tekinthetó, ezért az IBM a nemi különbségeket nem méri. Wilhelm, Brownhill és Boyce (2000) egy későbbi prospektív vizsgálatukban leírják, hogy a mérőeszköz a depresszióra nem érzékeny: a Gondoskodás skála egyáltalán nem, míg a Kontroll skála egy minimális, de szignifikáns változást mutatott, azaz, a javuló depresszióra csökkent a mértéke. Ez azt mutatja, hogy kevésbé hajlamos a párját kritikusnak látni valaki, amikor nem depressziós, más a viselkedése, attribúciója, vagy ténylegesen változtak a házastárs jellemzői. A gondoskodás észlelésben nem történik változás. Ugyanakkor azt is tételezik, hogy a kontroll kevésbé konzisztens összetevő, kevésbé robusztus, és ha lehet még szubjektívebb tapasztalat, mint a gondoskodás (Wilhelm és mtsai, 2000).

Elméletileg a „magas a gondoskodás” és „alacsony a kontroll” értékek a legkedvezóbbek, bár nem lehet figyelmen kívül hagyni, hogy bizonyos embereknek a kevesebb gondoskodás a kielégítő, míg mások igénylik partnerüktól az ellenőrzést. Wilhelm és Parker (1988) maguk is azt javasolják, hogy célszerú egy kapcsolati elégedettséget is mérő tételeket tartalmazó kérdőívet kitöltetni, hogy erre az aspektusra is rá tudjunk nézni. Megemlítik, hogy érdemes a szülői bánásmódot mérő eszközzel (PBI; Parker, Tulping, \& Brown, 1979) együtt használni, az intim kapcsolatrendszer jobb megértésének a vizsgálatához.

Amennyiben a gondoskodás és kontroll dimenziók kínálta elméleti lehetőségeket figyelembe vesszük, kategorizálhatóvá válik az intimitás, és a lehetőségeket címkézve a kategóriák a következők: „magas gondoskodás alacsony kontroll” = „optimális intimitás”, "magas gondoskodás - magas kontroll” = "kényszeres vonzalom”, ",alacsony gondoskodás - magas kontroll” = "vonzalom nélküli kontroll”, valamint ",alacsony gondoskodás - alacsony kontroll" = „intimitás hiánya” (Wilhelm és Parker, 1988). 
Összességében egy egyszerú és hatékony eszköznek tekintik az intimitás centrális konstruktumainak a mérésére, különös tekintettel a kockázatokat és következményeket vizsgáló kutatásokban.

\subsection{Az Intim Kötődés Mérése kérdőívvel kapott eredmények}

Az IBM kérdőívet megjelenése óta számos kutatásban használták, elsősorban angolszász területen, ausztrál mintán, de japán és vietnámi tapasztalatok is bizonyítják a méróeszköz megbízhatóságát. Wilhelm és Parker (1990) megvizsgálta 5 éves utánkövetéssel (1983-1988) a kérdőív megbízhatóságát, a konzisztenciát mutató korrelációs értékek 0,48-0,50 közé estek. A mintát alcsoportokra bontották: ugyanabban a párkapcsolatban élőkre és azokra, akiknél időközben megváltozott a partner. Azt találták, hogy a gondoskodás szignifikánsan csökkent az öt év alatt. Mivel mérsékelt erősségú volt a korreláció a teljes mintán és ott is, ahol nem változott a partner, felvetették, hogy az IBM egy állapotot mérő eszköznek tekinthető. Ez azt jelenti, hogy bizonyos változások a pár percepciójában idővel várhatóak, főként, ha fiatal felnőttekról beszélünk, amilyen a vizsgálati mintájuk volt.

Brennan és Wamboldt (1990) arra voltak kíváncsiak, hogy a család élményének megtapasztalása hogyan változik az idő folyamán, így többek közt feltételezték, hogy az aktuális kapcsolat a partnerrel, házastárssal analóg módon korrelál a szülőkkel való kapcsolat jellemzőivel. Mintájukban a fehéren kívül spanyol és fekete rassz is szerepelt, s mint kiderült a kontroll dimenzióra hatással volt, hiszen a nem fehér és a férfi résztvevók kontrollálóbbnak írták le a párjukat. Az IBM gondoskodás és kontroll dimenziói egymással negatív irányú, gyenge korrelációt mutattak. A szülői bánásmód és intim kötődés között az anyák esetében volt mérhető, de igen alacsony öszszefüggés: az anyai gondoskodás nagyon gyenge pozitív együttjárást mutatott a pár felől észlelt gondoskodással és gyenge negatív korrelációt a kontrollal, az anyai kontroll pedig szintén gyenge, pozitív irányú együttjárást mutatott a pár részéról észlelt kontrollal. Az IBM gondoskodás dimenziója közepes mértékú negatív, míg a kontroll dimenziója közepes erősségú pozitív együttjárást jelez a Family Assesssment Device - General Functioning Scale rövid változatával (FAD-GF; Byles, Byrne, Boyle, \& Offord, 1988). A FAD a családi aktivitás hat típusát öleli fel: problémamegoldás, kommunikáció, szerepek, affektív válaszkészség, affektív belevonódás és viselkedés kontroll. Szoros együttjárást mutat a családi diszfunkció számos indikátorával, mint amilyen például a házassági diszharmónia és erőszak, válás, szülők alkoholizmusa, mentális betegségek. Ezen összefüggések tudatában felmerülhet az intimitással való relatíve erős együttjárás folytán a kérdés, hogy vajon a párkapcsolati gondoskodás és kontroll mennyiben lehet prediktora a családi múködéseknek. 
A nemzetközi porondon végzett kutatásokból a Japánban készült házassági korrelátumokat feltáró vizsgálatban használták az IBM-et 61 házaspárnál (Furukawa és mtsai, 2002). A mintán magas Cronbach-a értékeket mértek: 0,87 és 0,86-ot. Céljuk a gyermekkorban észlelt szülői bánásmód és felnőttkori intim kapcsolat összefüggéseinek vizsgálata volt, személyiségjellemző́k bevonásával (NEO-Five Factor Inventory; Costa \& McCrae, 1992). Eredményeik szerint gyenge pozitív együttjárást mutatott az anyától kapott gyermekkori gondoskodás a férj részéről észlelt gondoskodással, valamint az anyai túlvédés a férj kontrolljával. A Lelkiismeretesség és gondoskodás gyenge pozitív együttjárást, a Barátságosság és kontroll pedig közepesen erós negatív együttjárást jelzett a férjjel kapcsolatban. Ha a férj magas pontszámot kapott a Nyitottság skálán, gondoskodóbb volt a házasságában, a korreláció ez esetben gyengének bizonyult. Ezek szerint az észlelt intimitás és bizonyos személyiségjellemzők mérsékelt erősségú együttjárása is igazolható.

Fischer, Tran és Tran (2014) tanulmányukban bemutatják azt a két részben (2006 és 2010) lezajlott vietnámi kutatást, amely várandós és frissen szült női populáción $(N=783)$ validálta a méróeszközt. Az eredetihez hasonlóan, a gondoskodás és kontroll faktorokat replikálták, a Cronbach-a értékek pedig 0,68 és 0,83 között mozogtak. A skálák átlagértékei szignifikáns együttjárást mutattak a várt irányokban. A gondoskodás a melegség és bizalom indikátorának bizonyult, jelezte, hogy a nők mennyire tudták rábízni magukat a partnerükre, mennyi támogatást kaptak tőle. A magas kontroll a pár részéról tapasztalt félelemmel és aktuális erőszakos megnyilvánulásokkal járt együtt. A gondoskodás protektív, a kontroll rizikó tényezőnek bizonyult a nők mentális egészségi állapotát illetően (generalizált szorongás, diagnosztizált depresszió és pánik) a perinatális időszakban.

Az intimitás kapcsolatát vizsgálták pszichiátriai kórképekkel, így Hickie és munkatársai (1990) diszfunkcionálisnak tekintik az intimitást, ha hiányzik a gondoskodás, mivel az erós rizikót jelent a nem melankolikus depreszszió fellépését tekintve, bár a túlzott mértékúnek észlelt kontroll nem járt együtt a betegség kockázatával. A nem melankolikus depresszióban szenvedők háromszoros valószínúséggel számoltak be gondoskodási deficitről, mint az ebben a betegségben nem szenvedők. Mielőtt tovább tárgyaljuk az IBM összefüggéseinek a vizsgálatát elsősorban a depresszív kórképekkel, rövid magyarázattal kell szolgálnunk a fogalomhasználatot illetően. A „nem melankolikus”, illetve „melankolikus depresszió” kifejezéseket használják az ausztrál nomenklatúrában, így a méróeszközt kidolgozó szerzőink is, ezért úgy döntöttünk, hogy eredményeik ismertetésénél nem változtatunk a megnevezéseken. Parker (2017) véleménye, hogy a melankólia a depresszió egyik kategóriája, amely pszichotikus, vagy nem pszichotikus állapotként nyilvánulhat meg, előfordulása a bipoláris epizódokat megélők- 
re jellemző. A 20. századtól sokféleképpen jelölték és különböztették meg a nem melankolikus depressziótól, így: (1) elsősorban genetikai és biológiai, nem pedig pszichoszociális tényezők határozzák meg, (2) viszonylag jól meghatározható klinikai tüneteket mutat, (3) minimális választ ad a placebóra (nagyjából 10\%), és (4) jobban reagál az olyan fizikai beavatkozásokra, mint az antidepresszáns gyógyszerek és elektrokonvulzív terápia, mint a pszichoterápiára. Napjainkban a melankóliát neurotranszmitter múködési zavarnak tartják, amely kihat a hangulatra, kognitív és pszichomotoros funkciókra (Parker \& Hadzi-Pavlovic, 1996), és a kérgi kapcsolatokra (Hyett, Breakspear, Friston, Guo, \& Parker, 2015). A definiálása és diagnózis felállítása problematikus, mert a többváltozós elemzések évtizedek óta egy sor úgynevezett endogén tünetet azonosítottak, mint meghatározót. Ezek közül sok azonban, pl. súlyváltozás, álmatlanság, csökkent libidó más állapotoknál is jelen vannak, így a nem melankolikus depresszióban, szorongásos állapotokban, és ezáltal ingoványossá teszik a meghatározást. Parker (2017) úgy véli, hogy a DSM-5-ben (APA, 2013) a melankólia „specifikus”nak minősül az „altípus" státusszal szemben, ami automatikusan nehezíti a major depressziótól való egyértelmú megkülönböztetését. Számos olyan tünet van, amely mind a melankóliára, mind a major depresszióra jellemző. A DSM-5 modell szerint minimális a különbség azok között, akik major depresszió melankóliával és azok között, akik major depresszió melankólia nélkül diagnózist kapnak. Szerinte a különbségtételnél fontos figyelembe venni a tünetek súlyosságának a megítélése és a pszichomotoros zavarok mellett a betegség lefolyását, valamint egyéb korrelátumait, beleértve a családtörténetet is. A differenciáldiagnózist segítendő kollegáival kidolgozták a klinikusok számára használatos Sydney Melancholia Prototype Index-et (SMPI; Parker és mtsai, 2011).

Mulder, Joyce, Sullivan és Oakley-Browne (1996) eredményei szerint az IBM gondoskodási pontszámai függetlenek a depresszió súlyosságától, és a személyiségjellemzóktől, nem disztingvál a melankólia és a nem melankolikus depresszió között, bár a különbségtételre akkor képes, ha előzetesen kezelt páciensekről van szó. Ez esetben szignifikánsan alacsonyabb gondoskodást érnek el Hickie és munkatársai (1990) eredményeihez hasonlóan azok, akik nem melankolikus depresszióban szenvednek. A kezelés kimenetelét azonban egyik esetben sem jelzi az IBM-en elért pontszám. Maga Wilhelm és munkatársai (2000) depressziós mintán végzett reliabilitásvizsgálata, a kezelés előtt és után, a gondoskodás értékekben változatlan, míg a kontrollban minimális elmozdulást mért, ami azt valószínúsíti, hogy a konstruktum a depressziótól függő megnyilvánulásokra nem érzékeny. Parker és Ritch (2001) szerették volna az IBM-mel mért intimitás és depresszió közötti kapcsolat ellentmondásait tisztázni, így egyéves utánkövetéses vizsgálatuk eredményeként a következő konklúziókra jutottak: a nem melankolikus de- 
presszióban szenvedők szignifikánsan nagyobb arányban észlelik a párjuk gondoskodását problematikusnak, mint a melankolikus depresszióval diagnosztizáltak. Ők azok, akik a nem jól funkcionáló (dysfunctional) kapcsolatban élők csoportjába kerültek, látszólag függetlenül a demográfiai jellemzőktől, a depresszió súlyosságától, krónikusságától, vagy ismétlődésétől. Az IBM értékei most is függetlennek bizonyultak számos olyan feltételezhetően torzító hatástól, mint például depresszió súlyossága és a „neuroticizmus". Bár az IBM nem tudta bejósolni ez esetben sem a depresszió kimenetelét, az világossá vált, hogy a gondoskodás pontszáma nőtt a jól funkcionáló kapcsolatban élőknek. Azt sugallják ezek a vizsgálatok, hogy van szerepe a nem kielégítő intimitásnak, a depresszió különböző fajtáinak az elkülönítésében, amire az IBM is alkalmas lehet.

Az IBM-mel hazai mintán végzett vizsgálatokban (Gérecz \& Hadházi, 2014; Hadházi, Andrek, \& Kekecs, 2017; Hadházi, Gérecz, \& Végh, 2011; Hadházi \& Hajdú, 2014; Hadházi, Mirnics, Végh, \& Gérecz, 2010) igazolódni látszott a Gondoskodás és Kontroll skálák, mint az intimitás két lehetséges összetevőjének az elkülönülése és összefüggése néhány pszichológiai tényezóvel.

2010-ben készült az IBM magyarra fordítása és első kipróbálása, 110 fős mintán, ahol a Cronbach-a értéke a Gondoskodás skála esetében 0,91, a Kontroll skálánál 0,91 volt. Már itt megmutatkoztak összefüggések a párkapcsolati elégedettséggel (Relationship Assessment Scale; RAS; Hendrick, Dicke, \& Hendrick, 1998), a gondoskodás 0,77 , a kontroll $-0,29(p<0,01)$ erősségú korrelációt jelzett.

Hadházi és munkatársai (2011) 455 fős magyar mintán magas tesztreteszt reliabilitásról és jól elkülönülő skálákról számoltak be. A mintából 257 fő sine morbo, 150 fő depresszióval diagnosztizált, 23 fó alkoholizmussal diagnosztizált és 25 fő depresszió és alkoholizmus diagnózissal rendelkezett. A Cronbach-a értéke a teljes mintán a következő volt: Gondoskodás skála 0,92 , Kontroll skála 0,88. A belső megbízhatóság a sine morbo és a különféle diagnózissal bíró almintákon is megfelelőnek bizonyult. Úgy túnik azonban, hogy a kontroll észlelése kevésbé megbízható módon történik az alkoholbetegséggel élők esetében (Cronbach-a =0,44), de minden más mintán igen magas a belső reliabilitás. A két skála egymással negatívan, közepes erősséggel korrelált. Nemi különbséget nem találtak a gondoskodás észlelésében, az egészséges csoportba tartozó férfiak viszont szignifikánsan kontrollálóbbnak ítélték a párjukat, mint a betegséggel éló férfiak. A depressziósoknál és az alkoholizmussal diagnosztizáltak esetében nem mértek nemi különbséget, de a depresszió és alkoholizmus diagnózisával is rendelkező nők szignifikánsan gondoskodóbbnak észlelték a társukat, mint ebből a csoportból a férfiak. A teljes mintán vizsgálva a kapcsolati elégedettséggel (RAS) pozitívan, közepes erősséggel korrelált a gondoskodás és negatívan 
közepes erősséggel a kontroll. A felnőtt kötődést (Experiences in Close Relationships Scale; ECR; Brennan, Clark, \& Shaver, 1998) jellemző elkerülés negatívan, közepes erősséggel járt együtt a gondoskodással és pozitív irányú, gyenge együttjárást mutatott a kontrollal; a szorongás mérsékelt erősséggel, negatívan korrelált a gondoskodással és pozitívan a kontrollal. A szülői bánásmód (H-PBI, Szülői Bánásmód Kérdőív; Tóth \& Gervai, 1999) és intimitás különböző mintázatai jelentek meg, s míg az egészséges csoportnál nagyon enyhe korrelációkkal találkozunk, addig a depresszióval diagnosztizáltaknál már az anyai túlvédés és kontroll elérte a 0,32 erősségú együttjárást, a többi összefüggés igen gyenge. Az alkoholizmussal diagnosztizált csoportnál közepes korreláció volt az apai és anyai túlvédés és kontroll észlelése között, az anyai szeretet furcsa módon pozitívan közepes erősséggel korrelált a kontrollal és gondoskodással is, míg az apai szeretet csak a gondoskodással. A kettős diagnózissal rendelkezőknél az apai és anyai korlátozás közepes mértékben, negatív irányban korrelált a kontrollal, az apai szeretet közepes erősséggel, pozitívan járt együtt a gondoskodással, az anyai túlvédés pedig közepes erősséggel, negatívan a gondoskodással. Úgy túnik patológiás esetekben erőteljesebbek az összefüggések a szülői bánásmód és intimitás között. Az időbeli stabilitás ellenőrzésére 35 fó töltötte ki az IBM kérdőívet, 3 hét különbséggel. A teszt-reteszt korrelációs együtthatók igen magasnak bizonyultak, a gondoskodásnál 0,93, a kontrollnál $0,91(p<0,001)$.

2014-ben Gérecz és Hadházi az intim kapcsolatokban megélt gondoskodás és kontroll összefüggéseit tanulmányozták a felnőtt kötődés (Közeli Kapcsolatok Élményei kérdőív; ECR), az egyéni fejlódési folyamatot befolyásoló szülői bánásmód (H-PBI) és a depresszió (Zung-féle Önértékelő Depresszió Skála) függvényében. Önbeszámolón alapuló 249 fős (73 férfi és 176 nő) vizsgálatuk eredményei szerint az IBM magas reliabilitási mutatókkal rendelkezett (Cronbach-a értékek: Gondoskodás skála: 0,92, Kontroll skála: 0,85). Az intimitás skálák egymással negatívan, közepes erősséggel korreláltak. A férfiak szignifikánsan magasabb értéket adtak a kontroll észlelésére, mint a nők. Igazoltnak találták a biztonságos kötődés és optimális intimitás közötti együttjárást, dimenzionális és kategoriális elemzéssel egyaránt. Azaz, a Gondoskodás skálán elért pontok közepes erósséggel, negatívan, míg a Kontroll skálán elért értékek a férfiak esetében közepesen, a nők esetében gyengén, pozitívan korreláltak az ECR kérdőív Szorongás és Elkerülés dimenzióin elért pontokkal. A kategoriális elemzés eredményei szerint az átlagok Tukey-Kramer-féle páronkénti összehasonlítása alapján a biztonságos kötődéshez képest a gondoskodás és a kontroll is szignifikánsan különbözött a félelemteli, belebonyolódott és elutasító kategóriáknál. A gondoskodást a félelemteli kategóriába soroltak észlelték a legalacsonyabbnak magas kontroll mellett, a kontrollt pedig az elutasítók észlelték a 
legmagasabbnak, alacsony gondoskodással együtt. Az intimitásban észlelt gondoskodás mindkét nemnél szignifikáns, de meglehetôsen gyenge negatív együttjárást mutatott a depresszióval. Az intimitás előrejelzésében különböznek a nemek. Hogy mennyire észleli egy férfi gondoskodónak a párját, azt az apai szeretet, a kötődési szorongás és az elkerülés magyarázza leginkább. A nőknél a kötődési szorongás, majd az elkerülés szignifikáns előrejelzői a gondoskodás észlelésének. A kontroll észlelését a férfiaknál a kötődési szorongás, elkerülés, az apai korlátozás, túlvédés és végül a szeretet jelezheti előre. Nőknél a kötődési elkerülés és anyai túlvédés bizonyultak az észlelt kontroll szignifikáns előrejelzőinek.

Hadházi és Hajdú (2014) 685 fős női mintán kisgyermekes anyák anyaságukkal kapcsolatos érzéseinek, hordozási szokásainak, valamint párkapcsolati megéléseinek és saját gyermekkori élményeinek összefüggéseit vizsgálták. A párkapcsolat minőségét meghatározó tényezőként fókuszáltak az intimitásra és a kapcsolati elégedettségre (RAS). Az IBM kérdőív reliabilitása igen jónak bizonyult, a Gondoskodás skála Cronbach-a értéke: 0,97, a Kontroll skáláé 0,91 volt. Azok az édesanyák, akik negatív változásokat éltek meg az anyaságuk révén (pl. „türelmetlenség”, , háttérbe szorítottság”, , ,fáradtság"), úgy észlelték, hogy párjuk kontrollálóbb magatartást tanúsít, mint akik ilyen negatív élményekról nem adtak számot. Azok, akik aggódtak az anyai kompetenciájuk miatt, szignifikánsan kevésbé észlelték gondoskodónak a párjukat, elégedetlenebbek voltak a párkapcsolatukkal, mint az anyai kompetenciájuk miatt nem, vagy csak kevéssé aggódók. Eredményeik szerint igen erős együttjárás mutatkozott a párkapcsolati elégedettség és az észlelt gondoskodás között, sőt a gondoskodásból 75,8\%-ban vált előrejelezhetóvé a kapcsolati elégedettség.

2017-ben Hadházi, Andrek, és Kekecs 114 várandós nő bevonásával vizsgálták a magzattal való kapcsolat és az intimitás összefüggéseit. A kérdőív belső megbízhatósága ez esetben is igen jónak bizonyult, a Gondoskodás skála Cronbach-a értéke 0,91, a Kontroll skáláé pedig 0,84 volt. A magzati kötődés (Intrauterin Kapcsolati Kérdőív) szignifikáns összefüggést mutatott a párkapcsolati intimitással: az észlelt gondoskodás kedvezőbb, míg az észlelt kontroll kedvezőtlenebb anya-magzat-kötődéssel járt együtt.

\section{Vizsgálatunk célja}

Vizsgálatunk célja a nemzetközi és hazai elővizsgálati tapasztalatok alapján megbízhatónak túnő, az intim kötődés mérésére alkalmas kérdőív, az Intimate Bond Measurement (IBM; Wilhelm \& Parker, 1988) magyar mintán történő validálása, a kérdőív magyar adaptációjával kapcsolatos pszichometriai elemzések végrehajtása, illetve a faktorstruktúra ellenőrzése. 
A validálás során a korábbi kutatási eredményeknek megfelelő, illetve azokat kiegészító tényezőket kívántunk bevonni, amelyek várhatóan összefüggésben állnak az intimitással, így a párkapcsolati kötődést, a kapcsolati elégedettséget, a szülői bánásmódot, a vonásszorongást, a depressziót és a társas támogatást vizsgáltuk. Reményeink szerint egy megbízható, elsősorban a prevencióban alkalmazható kérdőívvel bővülhet a pszichológiai eszköztár.

\section{Módszer}

\subsection{Minta és eljárás}

A keresztmetszeti, kérdőíves vizsgálatot a Károli Gáspár Református Egyetem Pszichológiai Intézetének Etikai Bizottsága engedélyezte (az etikai engedély száma: 407/2017/P), a Fejlődéslélektani Tanszéken folyó szocializáció, pár és családi interakció dinamika kutatás részeként.

A reprezentativitásra való törekvés érdekében próbáltunk falvakban, vidéki városokban és a fővárosban élőket is megszólítani, nőket és férfiakat egyaránt bevonni. A mintába kerülésnél fontos szempont volt az önkéntesség, a nagykorúság (az alsó korhatár a 18 év, felső korhatár nem volt meghatározva), a sine morbo egészségi állapot. Kizárási kritérium az analfabetizmus és a párkapcsolati tapasztalat hiánya volt. Az adatgyújtés a Károli Gáspár Református Egyetem pszichológia szakos hallgatóinak segítségével, elektronikus úton, hólabda módszerrel történt, 2018. február 18. és 2018. június 11. között. Az IBM kérdőív magyar adaptációját mindkét szerző, prof. Kay Wilhelm és prof. Gordon Parker is engedélyezte.

A mintába 1318 fő (250 férfi és 1068 nő) adatai kerültek. A nemi eltolódás igen jelentős a nők javára, ami a vizsgálat lebonyolításának a sajátosságából fakad. A toborzást végző egyetemi hallgatók hólabda módszerrel dolgoztak, elektronikus úton juttatták el, az anonim módon kitölthető kérdőív online elérhetőségét. Számos esetben tapasztalták, hogy a férfiak kevésbé vállalták a meglehetősen hosszú időt (kb. 40 percet) igénybe vevő kérdőívcsomag kitöltését, a munka honorálására pedig nem volt lehetőség, ami esetleg növelhette volna a részvételi motivációt. Bár az eltolódás nagyobbnak hat, G-Power elemzéssel ${ }^{1}$ közepes hatásméret feltételezésével, 5\%-os szignifikanciaszint, illetve 5\%-os statisztikai erő (másodfajú hiba) mellett meghatároztuk a minimálisan szükséges esetszámot, amely 400 fós mintaelemszámot eredményezett. Ez azt jelenti, hogy közepes hatásmértékeket alapul véve a

1 http://www.gpower.hhu.de/ 
minimális esetszámot messze meghaladó mintanagysággal rendelkezünk, így további alminták létrehozását, illetve esetleges utólagos súlyozásokat nem tartottunk szükségesnek.

A résztvevők életkorának átlaga 34,8 év (SD = 10,91 év) volt. A legfiatalabb kitöltő 18, a legidősebb 74 éves volt. A demográfiai adatokat az 1. táblázatban mutatjuk be.

1. táblázat. A vizsgálati minta demográfiai jellemzőinek összefoglaló táblázata

\begin{tabular}{|c|c|c|c|c|}
\hline \multicolumn{2}{|r|}{ Demográfiai adatok } & $\mathbf{n}$ & $\%$ & Valid \% \\
\hline \multirow[t]{2}{*}{ Nem } & férfi & 250 & 18,9 & 18,9 \\
\hline & nő & 1068 & 81,0 & 81,1 \\
\hline \multirow[t]{5}{*}{ Jövedelem } & átlag alatti & 34 & 1,3 & 2,6 \\
\hline & kissé az átlag alatti & 105 & 4,0 & 8,0 \\
\hline & átlagos & 604 & 22,9 & 45,8 \\
\hline & kissé az átlag feletti & 398 & 15,1 & 30,2 \\
\hline & átlag feletti & 177 & 6,7 & 13,4 \\
\hline \multirow{5}{*}{$\begin{array}{l}\text { Iskolai } \\
\text { végzettség }\end{array}$} & általános iskola & 12 & 0,5 & 0,9 \\
\hline & szakmunkásképző & 37 & 1,4 & 2,8 \\
\hline & szakközépiskola, gimnázium & 329 & 12,5 & 25,0 \\
\hline & főiskola, egyetemi hallgató & 202 & 7,7 & 15,3 \\
\hline & főiskola, egyetem & 738 & 28,0 & 56,0 \\
\hline \multirow{8}{*}{$\begin{array}{l}\text { Családi } \\
\text { állapot }\end{array}$} & házas & 647 & 24,5 & 49,1 \\
\hline & élettársi kapcsolat & 183 & 6,9 & 13,9 \\
\hline & párkapcsolat & 318 & 12,1 & 24,1 \\
\hline & elvált & 53 & 2,0 & 4,0 \\
\hline & egyedül élő & 104 & 3,9 & 7,9 \\
\hline & özvegy & 4 & 0,2 & 0,3 \\
\hline & jegyes & 5 & 0,2 & 0,4 \\
\hline & egyéb & 4 & 0,2 & 0,4 \\
\hline \multirow[t]{4}{*}{ Gyermek } & nincs gyermeke & 521 & 19,8 & 39,5 \\
\hline & van gyermeke & 746 & 28,3 & 56,6 \\
\hline & most várjuk az elsőt & 16 & 0,6 & 1,2 \\
\hline & vannak és most várjuk a következőt & 35 & 1,3 & 2,7 \\
\hline
\end{tabular}


1. táblázat folytatása

\begin{tabular}{|l|l|c|c|c|}
\hline \multicolumn{2}{|l|}{ Demográfiai adatok } & n & $\%$ & Valid \% \\
\hline \multirow{4}{*}{ Település } & fóváros & 579 & 22,0 & 43,9 \\
\cline { 2 - 5 } & város & 590 & 22,4 & 44,7 \\
\cline { 2 - 5 } & község & 100 & 3,8 & 7,6 \\
\cline { 2 - 5 } & falu & 40 & 1,5 & 3,0 \\
\cline { 2 - 5 } & egyéb & 10 & 0,4 & 0,8 \\
\hline
\end{tabular}

A saját bevallás szerint krónikus betegségben szenvedők (199 fő), illetve pszichológiai/pszichiátriai kezelésben részesültek (266 fó) kiszúrésre kerültek, így összesen 921 fó (180 férfi, 721 nő; átlagéletkor: 34,32 év, szórás: 10,59 év) került a sine morbo elemzésbe.

\subsection{Eszközök}

Vizsgálatunk során a minél pontosabb összefüggések feltárásához több kérdőívet is alkalmaztunk, valamint számos szociodemográfiai adatot rögzítettünk.

Szociodemográfiai adatok közül a következőket kértük: nem, életkor, iskolai végzettség, lakóhely, családi állapot, a gyermekeinek száma és az anyagi helyzet szubjektív besorolására (5 lehetőséggel: az átlag alattitól az átlag felettiig). Mivel alapvetően sine morbo vizsgálati személyekkel kívántunk dolgozni, külön megkérdeztük, hogy van-e krónikus betegsége és amennyiben pszichés problémája volt, azt milyen módon kezelték (pszichoterápia, gyógyszer, vagy mindkettő). A krónikus betegséget külön nem definiáltuk, csak rákérdeztünk, hogy „Van-e bármilyen krónikus betegsége?”, ha igent válaszolt, kértük a diagnózis nevét.

Intim Kötödés Mérése: a fentiekben ismertetett Wilhelm és Parker (1988) IBM magyar változatát használtuk (IBM-HU). A fordítást Hadházi Éva végezte, a visszafordítás Gérecz Ágnes és Végh Fruzsina bevonásával zajlott (2010). A visszafordított tételeknek az eredetivel való összevetését követően, a magyar változat korrekciója és konszenzus után, a véglegesítése történt. Jelen vizsgálatban az eredeti instrukciót használtuk, azzal a kiegészítéssel, hogy amennyiben aktuálisan nincs párkapcsolata, az utolsó párkapcsolatára vonatkoztatva töltse ki. A válaszadás a fent ismertetett módon történt.

Kapcsolati Elégedettség Skála (Relationship Assessment Scale; RAS; Hendrick és mtsai, 1998): a párkapcsolati elégedettség mérésére a Martos, Sallay, Szabó, Lakatos és Tóth-Vajna (2014) által validált Kapcsolati Elége- 
dettség Skála 8-tételes magyar változatát (RAS-H) használtuk. A kitöltő 1-tól 5-ig terjedő Likert típusú skálán értékelheti a kapcsolatának egyes jellemzőit az egyáltalán nem / kevéssé igaztól, a teljes mértékben / nagyon jellemzőig. Minél magasabb összpontszámot ér el valaki, annál elégedettebb a kapcsolatával. Számos kutatásban használták, változatos életkori, etnikai, sőt betegcsoportok esetében is. A jó pszichometriai tulajdonságai, rövidsége, érthetősége, egyszerú és gyors kitölthetősége és értelmezhetősége igen népszerúvé teszik a változatos kapcsolatokkal való elégedettség mérésére. A kérdőív belső megbízhatósága a jelen vizsgálatban megfelelőnek bizonyult (Cronbach-a: 0,92).

A Közvetlen Kapcsolatok Élményei Kérdôiv (Experiences in Close Relationships - Relationship Structures; ECR-RS; Fraley, Heffernan, Vicary, \& Brumbaugh, 2011): a méróeszközt Jantek és Vargha (2016) adaptálta magyarra a felnőtt kötődés korszerú mérési lehetőségeként. A kérdőív 10 tételt tartalmaz, amelyek különböző felnőtt kötődési személyekre vonatkoztathatóak (apa, anya, pár, barát). Vizsgálatunkban arra kértük a személyeket, hogy az apára, az anyára, illetve a jelenlegi párjukra vonatkoztatva töltsék ki, és amennyiben aktuálisan nincs párkapcsolatuk, az utolsó párkapcsolatukra gondoljanak. 7-fokú Likert-típusú skálán lehet jelölni az egyetértés mértékét, ahol az 1-es azt jelenti, hogy egyáltalán nem ért egyet az állítással, nem jellemző az állítás; a 7-es pedig azt jelenti, hogy teljes mértékben egyetért, teljesen jellemző. Az ECR-RS jó megbízhatósági mutatókkal rendelkezik, a feltáró faktorelemzés az elkerülés (6 tétel) és szorongás (3 tétel) alskálákkal a kötődés kétfaktoros elképzelését támasztja alá és a két dimenzió segítségével képes azonosítani a négy kötődési típust. A 10. tétel a magyar változatban sem sorolható be egyértelmúen egyik faktor alá sem. Jantek és Vargha (2016) a kérdőív konstruktum validitását megfelelőnek tartják: a magasabb párkapcsolati elkerülés és szorongás alacsonyabb általános jólléttel, párkapcsolati elégedettséggel és párkapcsolati megküzdési erőforrás értékekkel, valamint magasabb depresszió és párkapcsolati stressz értékekkel jár együtt. Mivel a legtöbb ember a biztonságosan kötődő típusba sorolható, bíztató, hogy a bizonytalan kötődés esetén jobban differenciál az eszköz. A kérdőív skáláinak belső megbízhatósága a jelen vizsgálatban megfelelónek bizonyult (Cronbach-a: 0,86-0,91).

Szülői Bánásmódot Kérdőív (Parental Bonding Instrument; PBI; Parker, Tulping, \& Brown, 1979): a szülói bánásmódot a PBI magyar változatával (H-PBI; Tóth \& Gervai, 1999) mértük, tekintettel a nemzetközi vizsgálatokra, ahol az IBM összefüggéseinek kutatásakor erősen preferált ez a mérőeszköz. A kérdőív 25 tételt tartalmaz külön-külön az édesanyára/nevelőanyára és édesapára/nevelőapára, és három faktort foglal magába, úgymint 1. „Szeretet”, 2. „Túlvédés”, 3. „Korlátozás”. A kérdőív egy 4-fokú Likerttípusú skálát használ. Válaszlehetőségek: „nagyon jellemző” (3), „általában 
igaz” (2), „alig” (1), „egyáltalán nem igaz” (0). A skálák belső megbízhatósága, azaz a Cronbach-a értékeik magasak, ahogy a teszt-reteszt korrelációs együtthatók is. Az alskálákon elért magas pontszám intenzív szülői szeretetet, túlvédést és korlátozást jelez. Tóth és Gervai (1999) úgy vélik, hogy a kérdőív pszichometriai mutatói megfelelőek, a normatív adatai hasonlítanak a külföldi és hazai vizsgálatok eredményeként kapott adatokhoz, így használatát normál és klinikai mintán egyaránt javasolják. Mintánkon a kérdőív skáláinak belső megbízhatósága megfelelőnek bizonyult (Cronbach-a: $0,65-0,94)$.

Vonásszorongás skála (State-Trait Anxiety Intentory - Trait Anxiety Scale; STAI-T; Spielberger, Gorsuch, \& Lushene, 1970; magyar változat: Sipos \& Sipos, 1978): a vonásszorongást mérő, 20 kérdést tartalmazó kérdőív Likerttípusú skálát használ, ahol tételenként négy lehetőség közül választva jellemezheti magát a vizsgálati személyt, aszerint, hogy általában hogyan érzi magát. Az egyetértés mértéke 1-4 pontozható az „egyáltalán nem”, „valamennyire", „eléggé”, vagy "teljesen/nagyon” válaszoknak megfelelően. A maximálisan elérhetó pontszám 80 , a minél magasabb pontérték a fokozottabb vonásszorongást jelöli. A kérdőívet a széleskörú gyakorlati elterjedtsége, közérthetősége miatt választottuk. Saját vizsgálatunkban a kérdőív belső megbízhatósága megfelelőnek bizonyult (Cronbach-a: 0,91).

Zung-féle Önértékelő Depressziót Skála (Zung, 1965; magyar változat: Simon, 1988): a 20 tételból álló kérdőív 4-fokú Likert-típusú skálán méri a depresszió összes tünetét, felöleli a pszichés és fiziológiai alkotóit, a DSM-IV szimptóma legtöbb kritériumát lefedi. Jól alkalmazható a depresszió felderítésében, a depressziós betegek állapotváltozásának nyomonkövetésében, és kezelés alatti szimptomatikus változások kimutatásában. Kiegészítő klinikai eszközként a diagnosztikus munkában, kutatási munkában, csoportosan és egyénileg is használják. Kvantitatív módon mér, az összpontszámot az egyes tételekhez tartozó pontszámok összege adja meg. A depresszió mértéke a következők szerint osztályozandó: 56 pont felett súlyos, 48-55 pont között közepes, 41-47 pontok között enyhének tekinthető. Nem valószínúsíthető depresszió 40 pontértéken, vagy alatta (Ágoston \& Szili, 2001). Zung meghatározta az ÖDS-indexet, amivel a tényleges nyerspontértékek összegét tizedes értékben fejezte ki (ld. Simon, 1988, 181. o.). Azonban kiemelendő, hogy a kérdóív nem alkalmas a depresszió diagnózisának felállítására, csupán becslőskálai támpontokat ad, így vizsgálati személyeinknél a depresszió skálán elért értékkel dolgozunk, becslésre vállalkozunk, számolva azzal, hogy 48 pont fölött nem zárható ki a depresszió. Saját mintánkon a kérdőív belső megbízhatósága megfelelőnek bizonyult (Cronbach-a: 0,85).

MOS Társas Támasz Kérdőív (MOS Social Support Survey; MOSS SSS; Sherbourne \& Stewart, 1991): a kérdőív magyar adaptációját Sz. Makó és munkatársai (2016) végezték. A mérőeszköz a három faktor (Érzelmi-infor- 
mációs támasz, Pozitív szociális interakción alapuló támasz és Instrumentális támasz) segítségével, megfelelő megbízhatósággal méri a társas támogatottságot, a belső konzisztencia értékei és a teszt-reteszt reliabilitás értékei egyaránt magasak. Egy kérdés a szociális háló kiterjedtségét azonosítja, 19 pedig egy 5-fokú Likert-típusú skálán (a soha [1], és mindig [5] végpontok között) segít meghatározni, hogy milyen támaszfajta milyen gyakran áll az illető rendelkezésére. Az elérhető pontszámok 19 és 95 között alakulhatnak. A skálákon elért magasabb pontszám nagyobb mértékú társas támogatást jelez. A kérdőív skáláinak belső megbízhatósága a jelen vizsgálatban megfelelőnek bizonyult (Cronbach-a: 0,89-0,95).

\subsection{Statisztikai elemzések}

A statisztikai elemzéseket részben IBM SPSS 25.0 programcsomagban, részben pedig ROPStat programcsomagban végeztük el, valamint a konfirmatív (megerősítő) faktorelemzést STATA 15.0 programcsomag segítségével folytattuk le.

A csoportok közötti különbségek vizsgálata során azt a stratégiát alkalmaztuk, hogy miután a normalitás a legtöbb változó esetében sérült, ezért a hagyományos varianciaanalízis (illetve két csoport esetében kétmintás $t$-próba) mellett minden esetben sztochasztikus homogenitás (két csoport esetében sztochasztikus egyenlőség) vizsgálatokat is elvégeztünk (ld. Takács, 2012; Takács, 2016; Vargha, 2015). Hasonlóan, több módszerrel vizsgáltuk a normalitást is (Kolmogorov-Szmirnov-teszt, valamint ferdeség, illetve csúcsosság segítségével egyaránt teszteltük). Szintén ezt az irányelvet követtük a korrelációs vizsgálatok esetében is: a Pearson-féle korrelációs együttható mellett a Spearman-, és Kendall-féle rangkorrelációs együtthatókat is kiszámítottuk. Mind a csoportok összehasonlítása esetében, mind a korrelációs vizsgálatok során a hagyományos tesztek eredményeit ismertetjük, de több fontos korlátozó tényező alkalmazása mellett. A korrelációk esetében két korlátozást alkalmaztunk. Egyrészt, csak akkor tekintettük relevánsnak az adott korreláció mértékét, ha annak mértéke meghaladja 0,3-as abszolútértéket (Cohen, 1992). Másrészt minden egyéb vizsgálatban is, a próbák erejét (másodfajú hiba) és elsőfajú hibáját (szignifikancia) is figyelve, a már hivatkozott Cohen-féle hatásmértékeket taglaló tanulmány alapján (Cohen, 1992), a hagyományos 5\%-os döntési szint helyett $p<0,01$ (1\%-os) szignifikanciaszintet alkalmaztuk.

A csoportok összehasonlítása során szintén Cohen (1992) hatásmértékeit nézve meggyőződtünk arról, hogy az összehasonlításhoz alkalmazott módszerek 95\%-os szignifikanciaszint mellett is kellő hatásmértéket biztosítanak, megfelelő erősséget tartva a próbák során. Cohen (1992) számításai 
szerint a korrelációs együttható és az ANOVA elemzések során, 0,01-es szignifikanciaszint mellett még kis hatásmérték esetében is 1000 fó alatti mintanagyságot követelhetünk meg - ez pedig esetünkben még a különböző csoportok kizárása, illetve külön válogatása esetében is fennáll. Cohen számításait G-Power és Jamovi programok segítségével is ellenőriztük. Továbbá, minden vizsgálatunkat bootstrap szimulációval is kiegészítettük és a kapott értékek konfidencia intervallumát is vizsgálat tárgyává tettük. A vizsgálatokhoz a hagyományos elemzések táblázatait közöljük azon feltétel mellett, ha hasonló irányú, mértékú különbségeket/együttjárásokat mutattak mind a rangstatisztikai eljárások, mind pedig a bootstrap által szolgáltatott szimulációs eredmények (Efron \& Gong, 1983).

\section{Eredmények}

\subsection{Strukturális elemzés és megbízhatóság}

A korábbi elemzések, illetve vizsgálatok alapján az IBM kérdőív egy elég stabil, kétfaktoros struktúrát mutatott, így első lépésként megerősítő (konfirmatív) faktorelemzés segítségével ellenőriztük a javasolt faktorstruktúrát. Ezt az elemzést a teljes mintán hajtottuk végre, függetlenül a sine morbo csoport definíciójától.

Az elemzésben részben a STATA15.0 verzióját, részben pedig az $\mathrm{R}$ programcsomag Lavaan (Rosseel, 2012) eljárást alkalmaztuk. Azonos eredményeket kaptunk mindkét programcsomagban az 1. ábrán bemutatott faktorstruktúrára.

Az elemzés RMSEA értéke 0,083, SRMR értéke 0,061 volt, tehát hajszálnyival, de elmaradt az elvárt szinttől. Ezt erősítették meg az illeszkedési mutatók is, a CFI értéke 0,891, míg a TLI érték 0,880 volt. Azonban a feltáró faktorelemzés (ML eljárással, VARIMAX rotációval) igen magas KMO érték mellett (0,961, a Bartlett-teszt $\chi 2$-értéke 20946,6; $p<0,001)$ futott le. Minden kommunalitás 0,30 feletti volt, valamint az anti-image mátrix korrelációs értékei is mind 0,85 felett voltak. A feltáró elemzés ugyancsak kétfaktoros modellt adott, amelynek magyarázó ereje az eredeti 24 változó helyett 2 faktort alkalmazva 53,7\%-os volt és a faktorokon való elhelyezkedések VARIMAX rotáció után ugyanazok voltak, mint a megerősító elemzés által ellenőrzött, korábbi vizsgálatok által ajánlott struktúra. Így elfogadtuk, hogy a magyar mintán lényegében ugyanazon faktorsturktúra rajzolódik ki, mint amit a nemzetközi szakirodalom is javasol, illetve igazolt. Emellett a fenti struktúra Cronbach-a értékei megfelelően magasak voltak: az első faktorba (Gondoskodás) rendeződő itemek skálájának alfa értéke 0,94, míg a második faktoré (Kontroll) 0,91 volt. 


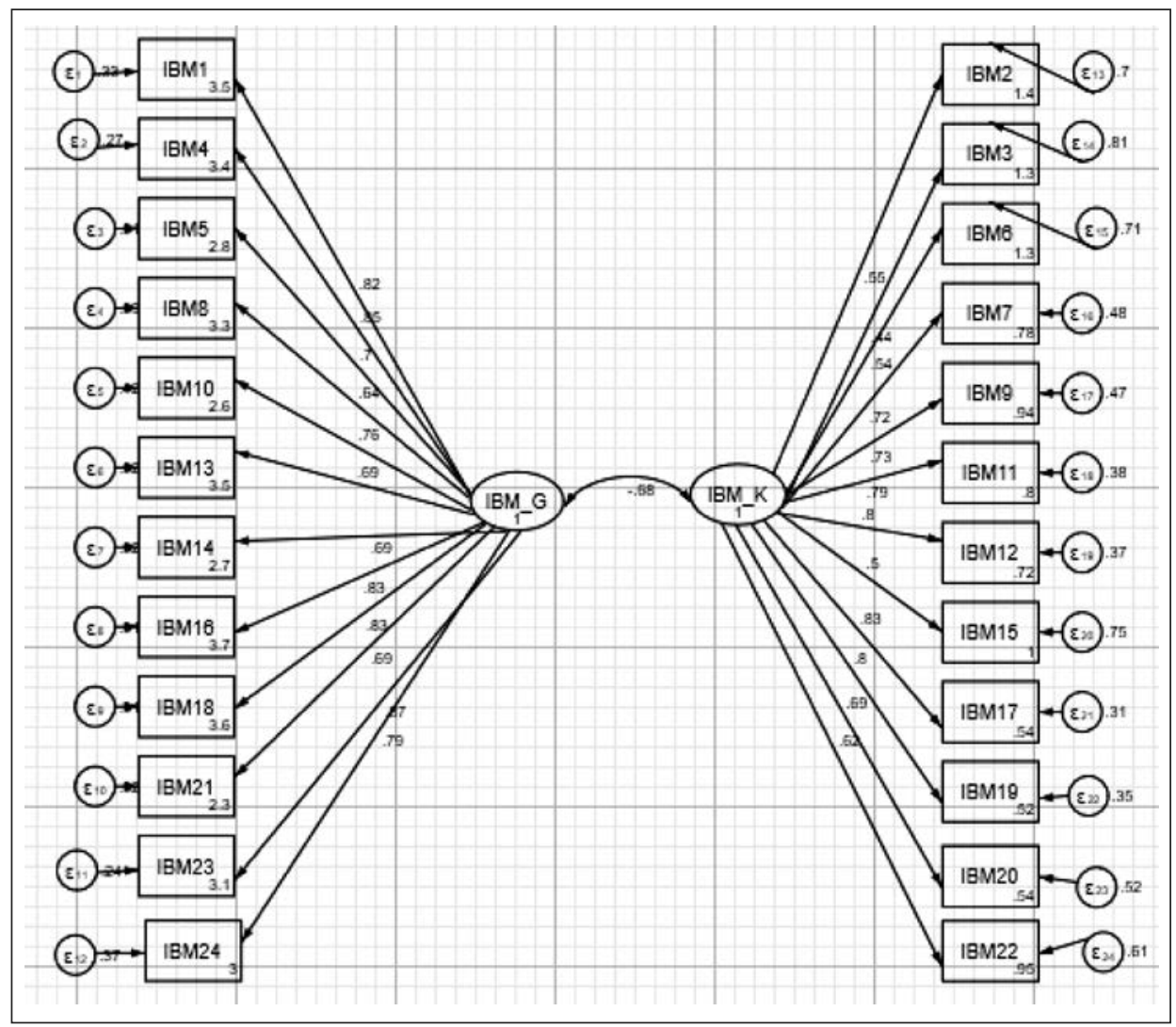

1. ábra. IBM-HU faktorstruktúrája a megerősítő faktorelemzéshez, STATA15.0 programban

\section{2. Összefüggések a szociodemográfiai mutatókkal}

A sine morbo csoportban megvizsgáltuk, hogy az alábbi változók mentén vannak-e különbségek az IBM-HU Kontroll, illetve Gondoskodás skálái mentén (többszempontos ANOVA elemzés, interakciós hatásokkal).

A 2. táblázatból látható, hogy sem a nemre, sem az anyagi helyzetre, iskolai végzettségre, családi állapotra, gyerekek meglétére vagy azok számára, illetve lakóhely típusára a sine morbo csoportokban nincsenek szignifikáns eltérések (egyetlen esetben sem haladja meg a 3\%-os magyarázó erőt (nemhogy az elvárt, közepesnek tekinthető $10 \%$-ot) sem az adott főhatás tekintetében). Vizsgáltuk a csoportok interakciós hatásait is (páros interakciókat, mert egyes csoportok esetszámai további rétegbontásokat nem tettek lehetővé), azonban nem tapasztaltunk megfelelő hatású interakciós együttjárásokat/különbségeket sem. Ez teljesült akkor is, amikor az életkori hatásokat 
kovariáns változóként szúrtük, tehát megállapítható, hogy az életkori hatásoktól függetlenül a fenti demográfiai változók érdemben nem hozhatók kapcsolatba az IBM-HU kontroll, illetve Gondoskodás skálájával a sine morbo mintán.

Mindez azt jelenti, hogy a sine morbo almintán az IBM-HU Kontroll, illetve Gondoskodás skálákon nem találtunk olyan szociodemográfiai mutatókat, amelyek kimutatható, szakmailag is releváns (legalább közepes hatású) eltéréseket eredményeztek volna.

2. táblázat. Varianciaanalízis fóhatásainak és kettes interakcióinak táblázata a magyarázottvariancia-hányadokkal az IBM-HU Gondoskodás és Kontroll skáláján a demográfiai változók mentén

\begin{tabular}{|c|c|c|c|c|c|c|c|}
\hline \multirow[t]{2}{*}{ Változók } & \multirow[t]{2}{*}{$\mathrm{df}$} & \multicolumn{3}{|c|}{ Gondoskodás } & \multicolumn{3}{|c|}{ Kontroll } \\
\hline & & F & $\mathbf{p}$ & $\begin{array}{c}\text { Parciális } \\
\text { ETA }^{2}\end{array}$ & F & $p$ & $\begin{array}{c}\text { Parciális } \\
\text { ETA }^{2}\end{array}$ \\
\hline Nem & 1 & 0,504 & 0,478 & 0,000 & 0,066 & 0,797 & 0,000 \\
\hline Anyagi helyzet (AH) & 4 & 1,222 & 0,300 & 0,005 & 1,427 & 0,223 & 0,005 \\
\hline Iskolai végzettség (IV) & 4 & 0,363 & 0,835 & 0,001 & 0,078 & 0,989 & 0,000 \\
\hline Családi állapot (CSÁ) & 8 & 1,527 & 0,143 & 0,011 & 0,331 & 0,954 & 0,002 \\
\hline Gyerek (van/nincs) (GY) & 3 & 0,723 & 0,538 & 0,002 & 2,868 & 0,036 & 0,008 \\
\hline Gyerekszám (GYSZ) & 7 & 0,983 & 0,442 & 0,006 & 2,275 & 0,027 & 0,015 \\
\hline Település (TEL) & 4 & 2,337 & 0,054 & 0,009 & 2,017 & 0,090 & 0,007 \\
\hline $\mathrm{NEM} \times \mathrm{AH}$ & 4 & 0,257 & 0,905 & 0,001 & 0,254 & 0,907 & 0,001 \\
\hline $\mathrm{NEM} \times \mathrm{IV}$ & 4 & 3,038 & 0,017 & 0,011 & 1,295 & 0,270 & 0,005 \\
\hline NEM × CSÁ & 5 & 1,902 & 0,091 & 0,009 & 2,807 & 0,016 & 0,013 \\
\hline $\mathrm{NEM} \times \mathrm{GY}$ & 2 & 0,226 & 0,798 & 0,000 & 0,289 & 0,749 & 0,001 \\
\hline $\mathrm{NEM} \times \mathrm{GYSZ}$ & 5 & 0,573 & 0,720 & 0,003 & 0,427 & 0,830 & 0,002 \\
\hline $\mathrm{NEM} \times \mathrm{TEL}$ & 3 & 0,324 & 0,808 & 0,001 & 0,418 & 0,740 & 0,001 \\
\hline $\mathrm{AH} \times \mathrm{IV}$ & 13 & 0,563 & 0,884 & 0,007 & 0,513 & 0,918 & 0,006 \\
\hline $\mathrm{AH} \times \mathrm{CSÁ}$ & 16 & 0,860 & 0,616 & 0,013 & 1,171 & 0,285 & 0,017 \\
\hline $\mathrm{AH} \times \mathrm{GY}$ & 6 & 0,761 & 0,601 & 0,004 & 0,972 & 0,443 & 0,005 \\
\hline $\mathrm{AH} \times \mathrm{GYSZ}$ & 16 & 1,764 & 0,031 & 0,025 & 1,087 & 0,362 & 0,016 \\
\hline $\mathrm{AH} \times \mathrm{TEL}$ & 14 & 2,042 & 0,013 & 0,026 & 1,754 & 0,041 & 0,022 \\
\hline IV × CSÁ & 13 & 1,145 & 0,316 & 0,014 & 1,002 & 0,447 & 0,012 \\
\hline $\mathrm{IV} \times \mathrm{GY}$ & 5 & 0,919 & 0,467 & 0,004 & 0,792 & 0,555 & 0,004 \\
\hline $\mathrm{IV} \times \mathrm{GYSZ}$ & 11 & 1,004 & 0,441 & 0,010 & 1,037 & 0,411 & 0,010 \\
\hline $\mathrm{IV} \times \mathrm{TEL}$ & 11 & 1,688 & 0,071 & 0,017 & 0,714 & 0,726 & 0,007 \\
\hline
\end{tabular}


2. táblázat folytatása

\begin{tabular}{|l|r|c|c|c|c|c|c|}
\hline \multirow{2}{*}{ Változók } & df & \multicolumn{3}{|c|}{ Gondoskodás } & \multicolumn{3}{c|}{ Kontroll } \\
\cline { 3 - 8 } & & $\mathbf{F}$ & $\mathbf{p}$ & $\begin{array}{c}\text { Parciális } \\
\text { ETA }^{2}\end{array}$ & $\mathbf{F}$ & $\mathbf{p}$ & $\begin{array}{c}\text { Parciális } \\
\text { ETA }^{2}\end{array}$ \\
\hline CSÁ $\times$ GY & 4 & 0,060 & 0,993 & 0,000 & 0,194 & 0,941 & 0,001 \\
\hline CSÁ $\times$ GYSZ & 11 & 1,609 & 0,091 & 0,016 & 0,959 & 0,482 & 0,010 \\
\hline CSÁ $\times$ TEL & 12 & 1,814 & 0,042 & 0,020 & 1,500 & 0,118 & 0,016 \\
\hline GY $\times$ GYSZ & 3 & 0,374 & 0,772 & 0,001 & 0,745 & 0,525 & 0,002 \\
\hline GY $\times$ TEL & 6 & 1,339 & 0,237 & 0,007 & 1,558 & 0,156 & 0,009 \\
\hline GYSZ $\times$ TEL & 14 & 0,947 & 0,507 & 0,012 & 1,349 & 0,172 & 0,017 \\
\hline
\end{tabular}

Emellett megvizsgáltuk azt is, hogy a teljes mintán akár a pszichés kezelés, akár a krónikus betegség megléte alapján definiált alcsoportok (van/nincs) mutatnak-e eltéréseket akár a kontroll, akár a gondoskodás mentén. A kétszempontos varianciaanalízis eredményei szerint (3-4. táblázat) a Gondoskodás skála esetében elmondható, hogy azoknál, akiknél nem volt bevallott pszichológiai/pszichiátria kezelés és krónikus betegség sem, azaz sine morbo-k, ott volt a legmagasabb a Gondoskodás skála átlaga, őket követték a krónikus betegségról számot adók, majd a pszichés kezelésben részesülők, végül a legalacsonyabb gondoskodás értéket azok érték el, akik mindkét típusú betegség egyidejú jelenlétéről beszámoltak. A Kontroll skála esetében éppen fordítva, a sine morbo csoportba tartozók a legalacsonyabb kontroll átlagot adták, a krónikus betegséggel kezeltek már magasabb kontrollról számoltak be, óket követték azok, akik mindkét kritériumot bejelölték és a legmagasabb kontroll értéket a pszichológiai/pszichiátria kezelés kezelésben részesülők érték el.

3. táblázat. Leíró statisztikai jellemzők az IBM-HU gondoskodás és kontroll változókra a pszichés és krónikus betegségekkel élők esetében

\begin{tabular}{|l|c|c|c|c|}
\hline \multirow{4}{*}{$\begin{array}{c}\text { Pszichológiai / pszichiátriai } \\
\text { kezelés }\end{array}$} & \multicolumn{2}{|c|}{ Gondoskodás } & \multicolumn{2}{c|}{ Kontroll } \\
\cline { 2 - 5 } & \multicolumn{2}{|c|}{ Krónikus betegség } & \multicolumn{2}{c|}{ Krónikus betegség } \\
\cline { 2 - 5 } & \multicolumn{2}{|c|}{ Nincs } & Van & \multicolumn{2}{c|}{ Nincs } & Van \\
\cline { 2 - 5 } & \multicolumn{2}{|c|}{$\begin{array}{c}\text { átlag (SD) } \\
\text { [n] }\end{array}$} & \multicolumn{2}{c|}{ átlag (SD) } \\
& \multicolumn{2}{|c|}{$[\mathrm{n}]$} \\
\hline \multirow{2}{*}{ Nincs } & $29,6(6,82)$ & $28,5(7,69)$ & $9,4(7,19)$ & $10,6(7,00)$ \\
& {$[921]$} & {$[132]$} & {$[921]$} & {$[132]$} \\
\hline \multirow{2}{*}{ Van } & $27,1(8,55)$ & $26,9(8,87)$ & $11,3(9,23)$ & $11,0(8,33)$ \\
& {$[199]$} & {$[66]$} & {$[199]$} & {$[66]$} \\
\hline
\end{tabular}


4. táblázat. Kétszempontos varianciaanalízis összefoglaló táblázata az IBM-HU gondoskodás és kontroll változókra a pszichés és krónikus betegséggel élők esetében

\begin{tabular}{|l|c|c|c|c|}
\hline \multicolumn{1}{|c|}{ Skála } & $\begin{array}{c}\text { Szórás- } \\
\text { homogenitás }\end{array}$ & $\begin{array}{c}\text { WELCH - } \\
\text { pszichés } \\
\text { betegség fóhatása }\end{array}$ & $\begin{array}{c}\text { WELCH - } \\
\text { krónikus } \\
\text { betegség fóhatása }\end{array}$ & $\begin{array}{c}\text { Interakció } \\
\text { (Johansen) }\end{array}$ \\
\hline Gondoskodás & $\begin{array}{c}F(3 ; 1314,0)=10,800 \\
(p<0,0001)\end{array}$ & $\begin{array}{c}F(1 ; 175,8)=7,969 \\
(p=0,005)\end{array}$ & $\begin{array}{c}F(1 ; 175,8)=0,880 \\
(p=0,350)\end{array}$ & $\begin{array}{c}\chi^{2}(1)=0,327 \\
(p=0,567)\end{array}$ \\
\hline Kontroll & $\begin{array}{c}F(3 ; 1314,0)=9,459 \\
(p<0,0001)\end{array}$ & $\begin{array}{c}F(1 ; 191,4)=3,168 \\
(p=0,077)\end{array}$ & $\begin{array}{c}F(1 ; 191,4)=0,426 \\
(p=0,515)\end{array}$ & $\begin{array}{c}\chi^{2}(1)=1,183 \\
(p=0,277)\end{array}$ \\
\hline
\end{tabular}

\subsection{Konvergens és divergens validitás}

A konvergens és divergens validitás meghatározásához kiszámítottuk az IBM-HU két skálájának korrelációját néhány jellemző és kérdóív értékeivel (5. táblázat). Az értékelés során - miként említettük a statisztikai módszertani összefoglaló fejezetben - a $p<0$,01-es szignifikanciaszint mellett döntöttünk. A statisztikai erőelemzés során kapott eredmények egybecsengtek Cohen (1992) eredményeivel, tehát a mintanagyságunk az első- és másodfajú hibahatárok (5\%-os szignifikanciaszint és másodfajú hiba) szinten tartásához elegendő volt. Valamint szintén Cohen (1992) javaslata nyomán kizárólag a 0,3-nál nagyobb abszolútértékú korrelációs együtthatókat tekintettük validnak (ezzel is korrigálva a nagyszámú összehasonlítás miatt az elsőfajú hibák valószínúségének emelkedését).

Miután valamennyi általunk alkalmazott skála normális eloszlása a Kolmogorov-Szmirnov teszt, valamint a ferdeség és csúcsosság eredménye alapján sérült 5\%-os szignifikanciaszint mellett (lásd Takács, 2016 és Vargha, 2015 útmutatását), ezért a különböző skálákkal való monoton, korrelációs (rangkorrelációs) kapcsolatokat mind a Pearson-féle hagyományos, mind pedig a Spearman-féle rangkorrelációs együttható, illetve Kendalltau-b monotonitási mérték segítségével megvizsgáltuk.

Szintén Vargha (2015) és Takács (2016) ajánlása alapján, csak azokat a kapcsolatokat tüntetjük fel a különböző kérdőívek skáláinak, alskáláinak együttjárásában, ahol mind a Pearson, mind pedig monotonitási mértékek esetében szignifikánsnak bizonyultak az együttjárások. Valamint tehát a nagy esetszámra és a több változó egyidejú összehasonlítására való tekintettel, a szignifikanciaszint megszigorítása $(p<0,01)$ mellett azt is kikötöttük, hogy kizárólag a 0,3-mas abszolút értékkel bíró korrelációs együtthatókat fogjuk elfogadható nagyságúnak tekinteni. A könnyebb áttekinthetőség kedvéért minden esetben a Pearson-féle korrelációs együttható értékét fogjuk feltüntetni. 
A korrelációs elemzések fóbb eredményei: a párkapcsolattal való elégedettség erős, pozitív irányú együttjárást mutatott a gondoskodással, közepes erősségú negatív korrelációt a kontrollal. A gondoskodás közepesen erős negatív, míg a kontroll szintén közepes erősségú pozitív együttjárást jelzett a felnőtt párkapcsolati kötődés elkerülés és szorongás alskálájával. A szülói bánásmódból az apai korlátozás emelkedett ki, a lelki problémák miatt kezeltek csoportjánál: minél korlátozóbbnak élték meg apjukat, annál kevésbé gondoskodónak és annál inkább kontrollálónak észlelték a párjukat, az összefüggés közepes mértékú. A depresszióval közepes erősségú negatív, a vonásszorongással gyenge és közepes mértékú negatív összefüggést jelzett a gondoskodás észlelése. A kontroll percepciója csak a krónikus betegséggel küzdőknél járt együtt közepes erősséggel a depresszióval és a vonásszorongással. A társas támasz mindhárom dimenziójának közepes mértékú pozitív együttjárását találtuk a gondoskodással, a kontrollal is következetesen negatív együttjárást tapasztaltunk, de ezek erőssége a gyenge és közepes között változott. 
5. táblázat. Az IBM-HU Gondoskodás és Kontroll skáláinak Pearson-féle korrelációs együtthatói csoportbontásban

\begin{tabular}{|c|c|c|c|c|}
\hline \multirow[t]{3}{*}{ Skálák } & \multicolumn{4}{|c|}{ KRÓNIKUS BETEGSÉG } \\
\hline & \multicolumn{2}{|c|}{ nem $(n=1120)$} & \multicolumn{2}{|c|}{ igen $(n=198)$} \\
\hline & $\begin{array}{l}\text { Gondos- } \\
\text { kodás }\end{array}$ & Kontroll & $\begin{array}{l}\text { Gondos- } \\
\text { kodás }\end{array}$ & Kontroll \\
\hline Gondoskodás (IBM-HU) & 1,00 & $-0,60$ & 1,00 & $-0,48$ \\
\hline Kontroll (IBM-HU) & $-0,60$ & 1,00 & $-0,48$ & 1,00 \\
\hline Anyai szeretet (H-PBI) & 0,22 & $-0,12$ & 0,21 & $-0,12$ \\
\hline Anyai túlvédés (H-PBI) & $-0,18$ & 0,19 & $-0,10$ & 0,25 \\
\hline Anyai korlátozás (H-PBI) & $-0,11$ & 0,06 & $-0,12$ & 0,09 \\
\hline Apai szeretet (H-PBI) & 0,23 & $-0,15$ & 0,14 & $-0,07$ \\
\hline Apai túlvédés (H-PBI) & $-0,15$ & 0,19 & 0,01 & 0,22 \\
\hline Apai korlátozás (H-PBI) & $-0,16$ & 0,16 & $-0,22$ & 0,23 \\
\hline $\begin{array}{l}\text { Párkapcsolattal való elégedettség } \\
\text { (RAS-H) }\end{array}$ & 0,83 & $-0,56$ & 0,85 & $-0,57$ \\
\hline Depresszió (Zung) & $-0,32$ & 0,17 & $-0,36$ & 0,32 \\
\hline ÖDS-index (Zung) & $-0,32$ & 0,17 & $-0,37$ & 0,32 \\
\hline Vonásszorongás (STAI) & $-0,30$ & 0,19 & $-0,38$ & 0,40 \\
\hline Elkerülés - pár (ECR-RS) & $-0,69$ & 0,54 & $-0,74$ & 0,50 \\
\hline Szorongás - pár (ECR-RS) & $-0,57$ & 0,40 & $-0,53$ & 0,34 \\
\hline Elkerülés - anya (ECR-RS) & $-0,14$ & 0,05 & $-0,11$ & 0,13 \\
\hline Szorongás - anya (ECR-RS) & $-0,15$ & 0,15 & $-0,10$ & 0,12 \\
\hline Elkerülés - apa (ECR-RS) & $-0,14$ & 0,09 & $-0,10$ & 0,06 \\
\hline Szorongás - apa (ECR-RS) & $-0,14$ & 0,14 & 0,01 & 0,07 \\
\hline $\begin{array}{l}\text { Érzelmi-információs támasz } \\
\text { (MOS SSS) }\end{array}$ & 0,36 & $-0,24$ & 0,46 & $-0,37$ \\
\hline $\begin{array}{l}\text { Pozitív szociális interakción } \\
\text { alapuló támasz (MOS SSS) }\end{array}$ & 0,48 & $-0,30$ & 0,53 & $-0,39$ \\
\hline $\begin{array}{l}\text { Instrumentális támasz } \\
\text { (MOS SSS) }\end{array}$ & 0,38 & $-0,30$ & 0,41 & $-0,29$ \\
\hline
\end{tabular}

Megjegyzés: H-PBI: Szülői Bánásmód Kérdőív, RAS-H: Párkapcsolattal való elégedettség, Zung: Zung-féle Önértékelő Depresszió Skála, STAI vonás: Spielberger-féle Vonásszorongás Skála, ECR-RS: Felnőtt kötődés párral, anyával, apával, MOS SSS: MOS Társas Támasz Kérdőív. A félkövér betúvel kiemelt együtthatók esetében $p<0,01$. 
5. táblázat folytatása

\begin{tabular}{|c|c|c|c|c|}
\hline \multirow[t]{3}{*}{ Skálák } & \multicolumn{4}{|c|}{ PSZICHÉS BETEGSÉG } \\
\hline & \multicolumn{2}{|c|}{ nem $(n=1053)$} & \multicolumn{2}{|c|}{ igen $(n=265)$} \\
\hline & $\begin{array}{l}\text { Gondos- } \\
\text { kodás }\end{array}$ & Kontroll & $\begin{array}{l}\text { Gondos- } \\
\text { kodás }\end{array}$ & Kontroll \\
\hline Gondoskodás (IBM-HU) & 1,00 & $-0,55$ & 1,00 & $-0,62$ \\
\hline Kontroll (IBM-HU) & $-0,55$ & 1,00 & $-0,62$ & 1,00 \\
\hline Anyai szeretet (H-PBI) & 0,22 & $-0,13$ & 0,16 & $-0,09$ \\
\hline Anyai túlvédés (H-PBI) & $-0,13$ & 0,21 & $-0,06$ & 0,17 \\
\hline Anyai korlátozás (H-PBI) & $-0,12$ & 0,06 & $-0,08$ & 0,08 \\
\hline Apai szeretet (H-PBI) & 0,19 & $-0,12$ & 0,25 & $-0,17$ \\
\hline Apai túlvédés (H-PBI) & $-0,12$ & 0,21 & $-0,14$ & 0,16 \\
\hline Apai korlátozás (H-PBI) & $-0,12$ & 0,12 & $-0,34$ & 0,32 \\
\hline $\begin{array}{l}\text { Párkapcsolattal való elégedettség } \\
\text { (RAS-H) }\end{array}$ & 0,82 & $-0,54$ & 0,86 & $-0,60$ \\
\hline Depresszió (Zung) & $-0,32$ & 0,19 & $-0,31$ & 0,16 \\
\hline ÖDS-index (Zung) & $-0,32$ & 0,19 & $-0,31$ & 0,16 \\
\hline Vonásszorongás (STAI) & $-0,31$ & 0,22 & $-0,27$ & 0,18 \\
\hline Elkerülés - pár (ECR-RS) & $-0,68$ & 0,50 & $-0,74$ & 0,59 \\
\hline Szorongás - pár (ECR-RS) & $-0,56$ & 0,37 & $-0,56$ & 0,42 \\
\hline Elkerülés - anya (ECR-RS) & $-0,12$ & 0,05 & $-0,10$ & 0,06 \\
\hline Szorongás - anya (ECR-RS) & $-0,15$ & 0,15 & $-0,07$ & 0,10 \\
\hline Elkerülés - apa (ECR-RS) & $-0,11$ & 0,06 & $-0,18$ & 0,13 \\
\hline Szorongás - apa (ECR-RS) & $-0,13$ & 0,14 & $-0,04$ & 0,09 \\
\hline $\begin{array}{l}\text { Érzelmi-információs támasz } \\
\text { (MOS SSS) }\end{array}$ & 0,39 & $-0,28$ & 0,37 & $-0,23$ \\
\hline $\begin{array}{l}\text { Pozitív szociális interakción alapuló } \\
\text { támasz (MOS SSS) }\end{array}$ & 0,46 & $-0,30$ & 0,57 & $-0,34$ \\
\hline $\begin{array}{l}\text { Instrumentális támasz } \\
\text { (MOS SSS) }\end{array}$ & 0,35 & $-0,26$ & 0,47 & $-0,37$ \\
\hline
\end{tabular}




\section{5. táblázat folytatása}

\begin{tabular}{|c|c|c|c|c|}
\hline \multirow[t]{3}{*}{ Skálák } & \multicolumn{4}{|c|}{ SINE MORBO } \\
\hline & \multicolumn{2}{|c|}{ nem $(n=397)$} & \multicolumn{2}{|c|}{ igen $(n=921)$} \\
\hline & $\begin{array}{l}\text { Gondos- } \\
\text { kodás }\end{array}$ & Kontroll & $\begin{array}{l}\text { Gondos- } \\
\text { kodás }\end{array}$ & Kontroll \\
\hline Gondoskodás (IBM-HU) & 1,00 & $-0,58$ & 1,00 & $-0,57$ \\
\hline Kontroll (IBM-HU) & $-0,58$ & 1,00 & $-0,57$ & 1,00 \\
\hline Anyai szeretet (H-PBI) & 0,17 & $-0,11$ & 0,23 & $-0,12$ \\
\hline Anyai túlvédés (H-PBI) & $-0,05$ & 0,17 & $-0,14$ & 0,21 \\
\hline Anyai korlátozás (H-PBI) & $-0,07$ & 0,06 & $-0,13$ & 0,06 \\
\hline Apai szeretet (H-PBI) & 0,19 & $-0,13$ & 0,21 & $-0,14$ \\
\hline Apai túlvédés (H-PBI) & $-0,06$ & 0,15 & $-0,15$ & 0,21 \\
\hline Apai korlátozás (H-PBI) & $-0,26$ & 0,27 & $-0,12$ & 0,12 \\
\hline $\begin{array}{l}\text { Párkapcsolattal való elégedettség } \\
\text { (RAS-H) }\end{array}$ & 0,85 & $-0,60$ & 0,82 & $-0,53$ \\
\hline Depresszió (Zung) & $-0,32$ & 0,21 & $-0,31$ & 0,16 \\
\hline ÖDS-index (Zung) & $-0,32$ & 0,21 & $-0,31$ & 0,16 \\
\hline Vonásszorongás (STAI) & $-0,31$ & 0,24 & $-0,29$ & 0,19 \\
\hline Elkerülés - pár (ECR-RS) & $-0,73$ & 0,56 & $-0,68$ & 0,50 \\
\hline Szorongás - pár (ECR-RS) & $-0,56$ & 0,40 & $-0,56$ & 0,38 \\
\hline Elkerülés - anya (ECR-RS) & $-0,10$ & 0,09 & $-0,13$ & 0,04 \\
\hline Szorongás - anya (ECR-RS) & $-0,07$ & 0,10 & $-0,16$ & 0,16 \\
\hline Elkerülés - apa (ECR-RS) & $-0,12$ & 0,09 & $-0,13$ & 0,07 \\
\hline Szorongás - apa (ECR-RS) & $-0,05$ & 0,08 & $-0,14$ & 0,15 \\
\hline $\begin{array}{l}\text { Érzelmi-információs támasz } \\
\text { (MOS SSS) }\end{array}$ & 0,39 & $-0,30$ & 0,37 & $-0,24$ \\
\hline $\begin{array}{l}\text { Pozitív szociális interakción alapuló } \\
\text { támasz (MOS SSS) }\end{array}$ & 0,52 & $-0,36$ & 0,46 & $-0,28$ \\
\hline $\begin{array}{l}\text { Instrumentális támasz } \\
\text { (MOS SSS) }\end{array}$ & 0,41 & $-0,34$ & 0,36 & $-0,26$ \\
\hline
\end{tabular}




\section{Megbeszélés}

Tanulmányunkban az Intim Kötődés Mérésére kidolgozott (IBM-HU) kérdőív elméleti hátterének, valamint magyar empirikus adatokon ellenőrzött pszichometriai jellemzőinek bemutatására vállalkoztunk. Eredményeink alapján, lényegében ugyanazon faktorstruktúra rajzolódott ki, mint amit a nemzetközi szakirodalom is igazolt, az így képződött Gondoskodás és Kontroll skálák egyenként 12 tételt tartalmaznak, magas belső konzisztenciával rendelkeznek és egymással közepes erősséggel, negatív irányban korrelálnak. A korrelációk nem adnak lehetőséget ok-okozati összefüggések megállapítására, így az eredményeink tárgyalásánál akkor is „csak együttjárásokra" hívjuk fel a figyelmet, ha ezt minden esetben külön nem emeljük ki. Tehát az, hogy az IBM-HU skálái egymással negatívan korrelálnak mindhárom (sine morbo, pszichológiai kezelésben részesült, krónikus betegségben szenvedő) vizsgált csoportban, azt jelenti, hogy testi és lelki állapotra való tekintet nélkül, valaki minél gondoskodóbbnak észleli a párját, annál kevésbé fogja kontrollálónak megélni és minél inkább kontrollálónak tapasztalja, annál kevésbé tartja gondoskodónak. Ez az eredmény teljesen megegyezik az eddigi hazai és nemzetközi vizsgálatok tapasztalataival (Hadházi és mtsai, 2011; Wilhelm \& Parker, 1988). Ez utóbbi jellemző alátámasztja a Wilhelm és Parker (1988) felvetését, hogy tulajdonképpen az intimitás ezen két összetevője meglehetósen homogén és minél inkább nő a kontroll egy intim kapcsolatban, annál inkább csökken a gondoskodás.

Az 1318 fós teljes mintánkon az intimitásnak egyik dimenziója sem függ a szociodemográfiai tényezőktől, így a nemtől, lakóhelytől, iskolai végzettségtól, jövedelmi helyzettől, családi állapottól, a gyermekek meglététól és számától. Hasonló tapasztalatokról számoltak be Wilhelm és munkatársai (2000) is. Mindez azt valószínúsíti, hogy a gondoskodás és kontroll észlelése a párkapcsolatban belső szükségletek által vezérelt, nem demográfiai tényezők által meghatározott. Clinebell és Clinebell (1970) úgy vélik, hogy az intimitás kölcsönös érzelmi elérhetőséget, nyitottságot feltételez a pár részéről. Meglátásuk szerint az intimitás növelhető, azáltal, ha a párok megtanulják, hogy érzelmileg jelen legyenek egymás számára. Eredményeink fényében, ennek a felvetésnek a párterápiás implikációit érdemes lehet tovább gondolni.

Az intimitás megtapasztalása a szülő-gyermek kapcsolatban kezdődik, így Parker és munkatársai (1979) ajánlása a gyermekkori élmények feltérképezésére jogos, s bár mintánkon minden korreláció szignifikáns volt a szülői bánásmód szeretet, túlvédés és korlátozás dimenzióval apára és anyára egyaránt, ezek mértéke többnyire nem érte el az abszolút értékben 0,3 feletti értéket, azaz a skálák közötti magyarázó erő 10\% alatt maradt. Ez alól kivételt képez az apai korlátozás, amely pozitívan korrelál a kontrollal és nega- 
tívan a gondoskodással a pszichológiai probléma miatt kezelésben részesültek csoportjánál, a sine morbo és krónikus betegséggel küzdő csoportoknál azonban nem találtunk érdemi együttjárást az élet első tizenhat évében tapasztalt szülői bánásmóddal. Ez az összefüggés azt valószínúsíti, hogy az apai bánásmód közül a korlátozás kiemelkedik, mint olyan tényező, amely a későbbiekben a lelki okok miatt kezelésben részesülőknél együtt jár a kontrollálóbb pár észlelésével. Az apai korlátozó magatartás ez esetben, nemtől függetlenül, a felnőttkori párkapcsolati intimitás észlelésénél a kontrolláló aspektusok megélésére érzékenyíthet, de azt is jelentheti, hogy valaki minél kontrollálóbbnak észleli a párját, annál inkább emlékszik úgy az édesapjára, mint aki gyermekként korlátozta őt. Az eredmény azért nem meglepő, mert bár számos külföldi és néhány hazai kutatásban vizsgálták a szülói bánásmód IBM-mel való kapcsolatát, nem találtak kimagasló erejú összefüggéseket egészséges mintán (Brennan \& Wambold 1990; Furukawa és mtsai, 2002; Hadházi és mtsai, 2011).

Ezzel szemben a párkapcsolattal való elégedettség mindhárom csoportban igen erős pozitív irányú együttjárást mutat a gondoskodással és erős, negatív irányú együttjárást a kontrollal. Az összefüggésből nem tudunk okokozatra következtetni, de az megállapítható, hogy a párkapcsolattal való elégedettség együtt nó az észlelt gondoskodással, míg a kontroll növekedése csökkenő elégedettséggel társul és természetesen mindkét összefüggés fordítva is érvényes, azaz minél gondoskodóbbnak észleli valaki a párját, annál elégedettebb a párkapcsolatával és minél kontrollálóbbnak észleli a párját, annál inkább csökken a párkapcsolattal való elégedettsége. Ez az öszszefüggés arra enged következtetni, hogy a kontroll, de fóleg a gondoskodás igen fontos komponensei a párkapcsolati elégedettségnek, ahogy az intimitásnak is a kapcsolattal való elégedettség.

Mivel a párkapcsolati elégedettséget tartja a szakirodalom az egyének általános jóllétének, lelki egészségének egyik fő meghatározójának, valamint a párkapcsolatok jó múködése és integritása szempontjából kiemelkedő faktornak (Dyrenforth, Kashy, Donnellan, \& Lucas, 2010), úgy túnik ez a megállapítás valószínúleg az intimitás észlelésére is kiterjeszthető lehet. Párterápiában különösen érdemes lehet ezt az aspektust szem előtt tartani. Murray, Holmes és Griffin (1996) érvelése szerint a kapcsolati elégedettség független attól, hogy a partner viselkedése a valóságban objektíve is tükröződik-e, vagy csupán a társa részéről szubjektív érzelmi hatások által előidézett „pozitív illúzió”. Mint Murray és munkatársai (2005) állítják, az, hogy milyennek észleli valaki a párját, meghatározza a kapcsolati biztonságot. Ezért is tekintjük releváns információnak a partner percepciójáról való szubjektív beszámolókat, amilyen az IBM is.

A kapcsolati elégedettség mellett a felnőtt párkapcsolati kötődés bizonyult olyan meghatározó tényezőnek, amely nem független az intimitástól. 
Eredményeink szerint a párra vonatkoztatott, Közvetlen Kapcsolatok Élményei (ECR-RS) kérdőív elkerülés és szorongás skálái az intimitás mindkét dimenziójával összefüggtek. A gondoskodás testi, lelki egészségi állapottól függetlenül közepes, vagy annál erősebb negatív, a kontroll közepesen erős pozitív együttjárást mutat az elkerüléssel és a szorongással. Mivel ismeretes, hogy annál biztonságosabb a kötődés minél alacsonyabbak a szorongás és elkerülés értékek, jól artikulálódik, hogy a gondoskodás negatív együttjárása azt jelenti, hogy annál biztonságosabban kötődik valaki, minél inkább gondoskodó magatartást észlel a párja részéről. A kontroll növekedésével a kötődési biztonság csökken, hiszen minél inkább kontrollálónak észleli a személy a párját, annál magasabb értékeket ér el az elkerülés és szorongás skálákon, vagyis csökken a kötődés biztonsága. Természetesen úgy is értelmezhetjük az eredményeket, hogy a biztonságos kötődés ad lehetőséget a gondoskodó megnyilvánulásokra, a bizonytalan pedig a kontrolláló magatartásnak kedvez. Eredményeink szerint a párkapcsolatban észlelt gondoskodás és kontroll nincs kimutatható kapcsolatban az aktuális anyai, illetve apai kötődési biztonsággal. Úgy tünik, hogy a szülőkhöz való kötődés egy teljesen más dimenzióban zajlik felnőttkorban, a párkapcsolati intimitásnak az általunk mért összetevői nincsenek kapcsolatban vele. Azt is elképzelhetőnek tartjuk, hogy ahogy végbe megy a szülőkről való leválás, a szülőkkel kapcsolatban érzett elkerülés és szorongás elválik a párkapcsolati intimitás megélésétől. Megállapítható, hogy az észlelt intimitásnak jelentős szerepe lehet a biztonságos kötődés kialakulásában, fenntartásában, ahogy a kötődésnek is az intimitás megélésében. Bartolomew (1990) az intimitást a felnőtt kötődés szempontjából közelíti meg. Az általa azonosított - az Önmagunk és a Másikról alkotott pozitív, vagy negatív megítélés alapján kialakított belső reprezentáció mentén - kötődési stílusok mutatják az egyén intimitáshoz való viszonyát. Négy esetet vázol fel, amelyekből az intimitás elkerülésének két módja a legkidolgozottabb. A félelemteli elkerülő, tudatosan vágyik a társas közelségre, de a következményektól való félelem miatt elkerüli azt. Önmagát érdemtelennek tartja mások szerelmére és támogatására. Az elutasító kerülni fogja az intimitás helyzeteket és mintegy énvédelemból tagadja, elfojtja az intimitásra való késztetéseit. Az önmagáról kialakított pozitív kép csökkenti annak a valószínúségét, hogy szembesüljön a társas szükségleteivel és szorongásaival (Bartolomew, 1990). Mikulincer (1998) és Simpson (1990) is a bizonytalan kötődésú emberek intimitás jellemzőjének az alacsony bizalmat, elégedettséget és elköteleződést tartják. A nemzetközi szakirodalomban megfogalmazódnak olyan ajánlások, miszerint a kötődéselmélet belső munkamodellje alkalmazható a felnőtt intimitás jobb megértésére, modellálására (Cassidy, 2001). A Johnson (2016) által kidolgozott Érzelmekre Fókuszáló Terápia (EFT) bizonyítottan jó eszköz lehet a sérült párkapcsolati kötődés gyógyításra, illetve az intimitás észlelésére való nyitottság, a megélésére való képesség fejlesztésére. 
A mentális jóllét szempontjából fontosnak tartottuk megvizsgálni, hogy a vonásszorongás, illetve depresszió milyen összefüggésben állhat az észlelt intimitással.

Eredményeink szerint a gondoskodás mindegyik csoportban negatívan, közepes erősséggel korrelál a Zung-féle Önértékelő Depresszió Skálán elért nyerspontokkal és ÖDS-index-szel, míg a kontroll csak a krónikus betegséggel küzdôk csoportjával korrelál pozitívan. Azaz minél magasabb pontszámot ér el valaki a depressziót méró skálán, annál kevésbé érzékeli gondoskodónak a társát, s ez akkor is érvényes, ha valamilyen krónikus betegséggel él, ha részesült lelki okok miatt kezelésben és akkor is, ha teljesen egészségesnek vallotta magát. Ez az eredmény azért fontos, mert azt sugallja, hogy a depresszió ellene hathat a gondoskodás észlelésének, illetve a kevesebb gondoskodást észlelők hajlamosabbak a depresszióra. A kontroll észlelésénél csak akkor van együttjárás a depresszióval, ha valaki krónikus betegségben szenved, ez esetben annál inkább kontrollálónak észleli a párját, minél magasabb pontot ér el a depressziót becslő skálán. Mivel a Zungféle Önértékelő Depresszió Skálán elért pontok alapján nem diagnosztizálunk, hiszen a depresszió típusáról, súlyosságáról, időtartamáról, lefolyásáról nem rendelkezünk ismeretekkel, csak becsülni tudjuk a depresszió meglétét, vagyis azt, hogy minél több pontot ér el a skálán a személy, annál valószínúbb, hogy depressziós (Simon, 1994; Ágoston \& Szili, 2001). A mintánkon a krónikus betegségben szenvedők növekvő pontértéke a depreszszió skálán és a párjuk részéről kontrollálónak észlelt viselkedés fokozódásának együttjárása állapítható meg, így joggal merül fel, hogy a krónikus betegség megléte fogékonyíthat a rosszabb hangulattal együtt járó kontrolláló magatartás észlelésére.

A vonásszorongás valójában minden csoportnál nem erősen, de stabilan negatívan korrelál a gondoskodással, a korreláció mértéke a nem sine morbo és a lelki okokból kezeltek csoportjánál nem éri el a 0,3 szintet. Ezt az eredményt azért tartjuk fontosnak, mert arra világít rá, hogy minél inkább jellemző vonása valakinek a szorongás, annál kevésbé észleli gondoskodónak a párját és fordítva. A kontrollal való pozitív együttjárás mintázata is ugyanez, de csak a krónikus betegségben szenvedők esetén éri el a releváns mértéket. Tehát a krónikus betegség mellett a vonásszorongás mértékének növekedése együtt jár a pár részéról észlelt fokozódó kontrollal, illetve minél inkább kontrollálóbbnak észleli a párját, annál magasabb a vonásszorongása. Az eredmények azt mutatják, hogy a krónikus betegség megléte egy rizikófaktor lehet a vonásszorongás és észlelt kontroll tekintetében, míg a gondoskodás stabilabban, negatívan korrelál a vonásszorongással. Olyan korábbi kutatási eredményekról nem tudunk, ahol a vonásszorongás intimitással való kapcsolatát vizsgálták volna.

Eredményeink valamelyest összhangban állnak azon kutatási adatokkal, amelyek az intimitás és a mentális egészség közötti összefüggések vizsgála- 
takor, a nem melankolikus depresszióval diagnosztizált pácienseknél problematikusnak találták az észlelt gondoskodást (Hickie és mtsai, 1990; Parker és Ritch, 2001). Ki kell emelnünk azonban, hogy saját mintánkon nem depresszióval diagnosztizáltak a résztvevők, csupán önbevallás alapján becsülhető a depresszió. A Zung-féle Önértékelő Depresszió Skálán mért növekvő értékek és a csökkenő gondoskodás együttjárása rajzolódott ki. Emellett - meglehetős újdonságként - a növekvő vonásszorongás és gondoskodás csökkenésének együttjárása igazolódott. Az IBM diszkriminatív validitása a nemzetközi trendhez hasonlóan (Mulder és mtsai, 1996; Wilhelm és mtsai, 2000) nálunk sem egyértelmú. Ugyanakkor elgondolkodtatónak tartjuk Harris és Brown (1985) megállapítását, miszerint az intim, bensőséges kapcsolat a párral véd a depresszióval szemben, sőt gyógyító funkciót tölt be, korábbi érzelmi problémák (Quinton, Rutter, \& Lidle, 1984) és gyász (Parker \& Hadzi-Pavlovic, 1984) esetén, bár esetünkben ez utóbbiakra vonatkozó mért adatunk nincs, úgy véljük, hogy diagnosztizált mintán mindenképpen érdemes lenne a kérdés vizsgálata.

A társas támogatás esetében a Gondoskodás skála a MOS SSS mindhárom alskálájával pozitív irányú, mérsékelt erősségú együttjárást mutatott, a testi-lelki egészségi állapottól függetlenül, ami azt jelenti, hogy az „érzelmi információs támasz” (pl.: tanácsot kap krízishelyzetben), „az instrumentális támasz" (pl.: konkrét kézzelfogható segítséget kap betegség esetén) és a „pozitív szociális interakción alapuló támasz" (pl.: van valaki, akivel a szabadidejét eltöltheti, kikapcsolódhat) és észlelt gondoskodás együtt jár. Az utóbbi skálával a kontroll is 0,3 feletti negatív összefüggést mutatott, jelezve, hogy a személy minél kevésbé érzi, hogy van valaki, akivel lazíthat, annál kontrollálóbbnak észleli a párját. Abban az esetben, ahol az egyén társas szükségletei kielégítésének a forrása nem kizárólag a párja, ott a részéról észlelt gondoskodás nő, illetve minél kevésbé akad valaki, akivel a rekreációs időt megossza, annál kontrollálóbbnak észleli a párját, és sajnálatos módon, amint azt az eredményeink mutatják, az észlelt kontroll növekedésével a kapcsolati elégedettség csökken. Természetesen az összefüggések fordított előjellel is érvényesek. Az instrumentális támasz, a lelki okokból kezelésben részesülóknél mutatott statisztikailag is releváns mértékú negatív együttjárást az észlelt kontrollal, ami azt jelenti, hogy minél inkább kap kézzelfogható segítséget valaki, annál kevésbé észleli kontrollálónak a párját és minél kevesebb a praktikus segítség, annál inkább nő a kontroll érzete. Mint látjuk, a lelki problémák miatt kezeltek érzékenyebbek a kontrollra, különösen, ha ehhez a viselkedéshez nem kapcsolódik nyilvánvaló praktikus segítségnyújtás a pár részéról. A társas támasz és intimitás ily módon való együttjárása alátámaszthatja, hogy bár a nukleáris családok elterjedésével a párkapcsolatra háruló teher nő, a társas támogatottság védelmet nyújthat. 
Munkánk gazdag tapasztalati anyagot szolgáltat, ám így is maradtak olyan tényezők, melyek az eredmények érvényességét korlátozhatják. Például, a sine morbo csoport kialakításához rákérdeztünk a krónikus betegség meglétére és a pszichológiai problémával való kezelésre, de tisztában vagyunk azzal, hogy a nemleges válasz nem feltétlenül szavatolja, hogy az illető nem rendelkezik valamely mentális betegséggel. Annak ellenére, hogy törekedtünk a reprezentativitásra, nem tudtuk teljes mértékben megvalósítani, például kiküszöbölni a nemi eltolódást a nők javára, amit végül a kitöltők nagy számával kompenzáltunk. Illetve nem hagyhatjuk figyelmen kívül a mintagyújtésból származó esetleges egyéb torzító hatásokat, úgymint a társadalmi kívánatosságnak való megfelelés, az objektivitás hiánya, hisz az önbevallásos kérdőívek esetében számolni kell a szubjektív torzítással, amit a teljes anonimitással igyekeztünk ellensúlyozni.

Összegezve, az IBM kétfaktoros szerkezetét igazoltuk, úgy véljük, hogy a gondoskodás és kontroll valóban meghatározó aspektusai az intimitásnak, amelyek közül a gondoskodás túnik stabilabbnak, egyetértünk Wilhelm és munkatársaival (2000), hogy a kontroll még ettől is szubjektívebb tapasztalat. A kérdőív maga, magas reliabilitással és megfelelő validitásjellemzőkkel rendelkezik. A nemzetközi ajánlásokkal összhangban egy megbízható mérőeszköznek tartjuk, amely jól alkalmazható az intimitás kutatását célzó vizsgálatokon túl a prevencióban, egyéni és párterápiában, hiszen nem érzékeny szociodemográfiai jellemzőkre. Elsősorban a gondoskodás észlelésének feltérképezésével olyan intervenciókat lehet foganatosítani, amelyek fókuszáltan segíthetik a párt egymás gondoskodó attitűdjének és viselkedésének a fel- és elismerésére, megerősítésére, fokozva ezzel a kapcsolati elégedettséget és a kötődés biztonságát. Cassidy $(2001,121$. o.) után, úgy véljük, hogy „,az igazság az intimitásban rejlik”, a kérdőív pedig jó eszköze lehet annak, hogy segítségével monitorozhatóvá váljon a különböző terápiás beavatkozások hatékonysága az intimitás alakulását illetően. A továbbiakban, mivel a feltárt együttjárások megerősítik az IBM-HU megbízhatóságát, érdemesnek tartjuk a mérőeszközzel újabb elemzéseket végezni, akár különböző betegcsoportokon is, hogy modellálni lehessen az intimitás prediktorait, bejósló erejét, elsősorban a párkapcsolati elégedettséggel való szoros együttjárása miatt. 


\section{Irodalom}

Altin, M., \& Terzi, S. (2010). How does attachment styles relate to intimate relationship to aggravate the depressive symptoms? Procedia Social and Behavioral Sciences, 2, 1008-1015. APA (2013). Diagnostic and Statistical Manual of Mental Disorders Vth Edition. Washington DC: American Psychiatric Association.

Ágoston, G., \& Szili, I. (2001). Diagnosztikus kérdőívek és tünetbecslő skálák. In J. Füredi, A. Németh, P. Tariska (Szerk.), A pszichiátria magyar kézikönyve, második kiadás (239-246). Budapest: Medicina Kiadó

Bárczi, G., \& Országh, L. (Szerk.) (1959-1962). A magyar nyelv értelmező szótára, Akadémiai Kiadó, Arcanum Kézikönyvtár, Arcanum Adatbázis Kiadó. Letöltve: 2018. 10. 11-én: https:/ / www.arcanum.hu/hu/online-kiadvanyok/Lexikonok-a-magyar-nyelvertelmezo-szotara-1BE8B/i-i-31843/intimitas-3250A/

Bartolomew, K. (1990). Avoidance of intimacy: An attachment perspective. Journal of Social and Personal Relationships, 7(2), 147-178.

Brennan, J.L., \& Wamboldt, F.S. (1990). From the outside in: examining how individuals define their experienced family. Communication Research, 17, 399-412.

Brennan, K.A., Clark, C.L., \& Shaver, P.R. (1998). Self-report measurement of adult attachment: An integrative overview. In J. A. Simpson, \& W. S. Rholes (Eds), Attachment theory and close relationships (46-76). New York: Guilford Press

Brennan, K.A., Shaver, P.R., \& Tobey, A.E. (1991). Attachment styles, gender and parental problem drinking. Journal of Social and Personal Relationships, 8 (4), 451-466.

Brown, G., \& Harris, T. (1978). Social origins of depression. A study of psychiatric disorder in women. London: Tavistock Publications

Byles, J., Byrne, C., Boyle, M.H., \& Offord, D.R. (1988). Ontario child health study: Reliability and validity of the general functioning subscales of the McMaster Family Assessment Device, Family Process, 27, 97-104.

Cassidy, J. (2001). Truth, lies and intimacy: An attachment perspective. Attachment and Human Development, 3(2), 121-155.

Clark, M.S., \& Reis, H.T. (1988). Interpersonal processes in close relationships, Annual Review of Psychology, 39, 609-672.

Clinebell, H. J., \& Clinebell, Ch.H. (1970). The intimate marriage. Letöltve: 2010. 07. 25-én: http:/ / www.religion-online.org/book/the-intimate-marriage/

Cohen, J. (1992). A power primer. Psychological Bulletin, 112(1), 155-159.

Costa, P.T., \& McCrae. R.R. (1992). Revised NEO Personality Inventory (NEO PI-R) and NEO Five-Factor Inventory (NEO-FFI): Professional manual. Odessa, Florida: Psychological Assessment Resources Inc.

Costello, C.G. (1982). Social factors associated with depression: a retrospective community study. Psychological Medicine, 12, 329-339.

Demunck, V.C., \& Korotayev, A. (2007). Wife-husband intimacy and female status in crosscultural perspective. Cross-Cultural Research, 41(4), 307-335.

Dyrenforth, P.S., Kashy, D.A., Donnellan, M.B., \& Lucas, R.E. (2010). Predicting relationship and life satisfaction from personality in nationally representative samples from three countries: The relative importance of actor, partner, and similarity effects. Journal of Personality and Social Psychology, 99(4), 690-702.

Efron, B., \& Gong, G. (1983). A leisurely look at the bootstrap, the jackknife and crossvalidation. American Staistician, 37(1), 36-48.

Erikson, E.H. (1991). Az életciklus: az identitás epigenezise. In E.H. Erikson (Szerk.), A fiatal Luther és más írások (437-498). Budapest: Gondolat 
Fischer, J., Tran, T.D., \& Tran, T. (2014). Validation of the Intimate Bond Measure for women who are pregnant or recently given birth in Vietnam, Asia Pacific Psychiatry 6, 28-37.

Fraley, R.C., Heffernan, M.E., Vicary, A.M., \& Brumbaugh, C.C. (2011). The Experiences in Close Relationships-Relationship Structures questionnaire: A method for assessing attachment orientations across realtionships. Psyhological Assessment, 23, 615-625.

Furukawa, T.A., Hori, S., Azuma, H., Nakano, Y., Oshima, M., Kitamura, T., et al. (2002). Parents, personality or partner? Correlates of marital relationships, Social Psychiatry and Psychiatry Epidemiology, 37, 164-168.

Gérecz, Á., \& Hadházi, É. (2014). Intimitás, a kötődés, szülői bánásmód és depresszió függvényében. In M. Vassányi, J. Fülöp, \& Zs. Mirnics (Szerk.), Kapcsolatban Istennel és emberrel. Pszichológiai és bölcsészeti tanulmányok (32-54). Budapest: L'Harmattan Kiadó

Hadházi, É., Andrek, A., \& Kekecs, Z. (2017). Előzetes eredmények egy magyar mintán kidolgozott Intrauterin Kapcsolati Kérdőív méréses tapasztalatairól - pilot study - Az anya-magzat kapcsolat párkapcsolattal és szülői bánásmóddal való összefüggéseinek vizsgálata. Mentálhigiéné és Pszichoszomatika, 18(3), 263-300.

Hadházi, É., Gérecz, Â., \& Végh, F. (2011). Az intimitás mérése - előzetes eredmények magyar mintán - “Hagyomány és megújulás". Poszter. A Magyar Pszichológiai Társaság Jubileumi XX. Országos Tudományos Nagygyúlése. Budapest, 2011. május 25-27.

Hadházi, É., \& Hajdu, I. (2014). Múlt- és jelenbeli tapasztalatok összefonódásai a párkapcsolatban és az anyaságban. Psychologia Hungarica Caroliensis, 2(1), 23-49.

Hadházi, É., Mirnics, Zs., Végh, F., \& Gérecz, Á. (2010). „Gondoskodás és kontroll az intim kapcsolatokban” „Egyén és kultúra. A pszichológia válasza napjaink társadalmi kihívásaira" A Magyar Pszichológiai Társaság XIX. Országos Tudományos Nagygyúlése, Pécs, 2010. május 27-29.

Harris, T., \& Brown, G.W. (1985). Interpreting data in aetiological studies of affective disorder: some pitfalls and ambiguities. British Journal of Psychiatry 27, 259-263.

Hatfield, E. (1988). Passionate and compassionate love. In R.J. Sternberg, \& M.L. Barnes (Eds.), The psychology of love (191-217). London: Yale University Press

Heller, P., \& Wood, B. (1998). The process of intimacy: Similarity, understanding and gender. Journal of Marital and Family Therapy, 24, 273-288.

Henderson, A.S., Byrne, D.G., \& Duncan-Jones, P. (1981). Neurosis and the social environment. Academic Press, Sydney.

Hendrick, S. S., Dicke, A., \& Hendrick, C. (1998). The Relationship Assessment Scale. Journal of Social and Personal Relationships, 15(1), 137-142.

Hickie, I., Wilhelm, K., Parker, G., Boyce, P., Hadzi-Pavlovic, D., Brodaty, H., et al. (1990). Perceived dysfunctional intimate relationships: a specific association with the nonmelancholic depressive subtype, Journal of Affective Disorders, 19, 99-107.

Hyett, M.P., Breakspear, M.J., Friston K.J., Guo, C.C., \& Parker, G.B. (2015). Disrupted effective connectivity of cortical systems supporting attention and interoception in melancholia. JAMA Psychiatry 72, 350-358.

Jantek Gy., \& Vargha, A. (2016). A felnőtt kötődés korszerú mérési lehetősége: A közvetlen kapcsolatok élményei - kapcsolati struktúra (ECR-RS) kötődési kérdőív magyar adaptációja párkapcsolatban élő felnőtt személyeknél, Magyar Pszichológiai Szemle, 71(3), 447-470.

Johnson, S.M. (2016). Az érzelmekre fókuszáló párterápia gyakorlata. Budapest: Oriold és Társai

Kikuchi, M., \& Snell, Jr. (2002). Chapter 6: Family environment variables and locus of control in intimate relationships. In W.E. Snell, Jr. (Ed). Student Research in psychology at Southeast State University. Cape Girardeau, MO: Snell Publications 
Laurenceau, J-P., Barett Feldman, L., \& Pietromonaco, P. R. (1998). Intimacy as an interpersonal process: the importance of self-disclosure, partner disclosure and perceived partner responsiveness in interpersonal exchanges. Journal of Personality and Social Psychology, 74 (5), 1238-1251.

Lavigne, G.L., Vallerand, R.J. \& Crevier-Braud (2011). The fundamental need to belong on the distinction between growth and deficit -reduction orientations, Personality and Social Psychology Bulletin, 37, 1185-1201.

Martos, T., Sallay, V., Szabó, T., Lakatos, Cs., \& Tóth-Vajna, R. (2014). A Kapcsolati Elégedettség Skála magyar változatának (RAS-H) pszichometriai jellemzői. Mentálhigiéné és Pszichoszomatika, 15(3), 245-258.

Mikulincer, M. (1998). Adult attachment style and affect regulation: Strategic variations in self-appraisals. Journal of Personality and Social Psychology, 75, 420-435.

Mikulincer, M., Florian, V., Cowan P., \& Cowan. C. (2002). Attachment security in couple relationships: A systemic model and its implications for family dynamics. Family Process, 41(3), 405-434.

Mulder, R.T., Joyce, P.R., Sullivan, P.F., \& Oakley-Browne, M.A. (1996). Intimate bonds in depression, Journal of Affective Disorders, 40 (I 996) 175-I78.

Murray, L.S., Holmes, G.J., \& Griffin, D.W. (1996). The self-fulfilling nature of positive illusions in romantic relationships: love is not blind, but prescient. Journal of Personality and Social Psychology, 71(6), 1155-1180.

Murray, L.S., Rose, P., Holmes, G.J., Derrick, J., Podchaski, E.J., Bellavia, G., \& Griffin, D.W. (2005). Putting the partner within reach: A dyadic perspective on felt security in close relationships. Journal of Personality and Social Psychology. American Psychological Association, $88(2), 327-347$.

O'Connor, P., \& Brown, B.W. (1984). Supportive relationships: fact or fancy. Journal of Social and Personal Relationships, 1, 159-175.

Parker, G. (2017). Diagnosing melancholic depression: some personal observations. Australasian Psychiatry, 25, 21-24.

Parker, G., \& Hadzi-Pavlovic, D. (1984). Modifications of level of depression in mother breaved women by parental and marital relationships. Psychological Medicine, 14, 125-135.

Parker, G., \& Hadzi-Pavlovic, D. (1996). Melancholia: a disorder of movement and mood. Cambridge: Cambridge University Press

Parker, G., \& Ritch, J. (2001). The influence of an uncaring partner on the type and outcome of depression, Journal of Affective Disorders, 66, 207-214.

Parker, G., McCraw, S., Blanch, B., Hadzi-Pavlovic, D., Synnott, H., \& Rees, A.M. (2013). Discriminating melancholic and nonmelancholic depression by prototypic clinical features. Journal of Affective Disorder, 144, 199-207.

Parker, G., Tulping, H., \& Brown, L.B. (1979). A Parental Bonding Instrument. British Journal of Medical Psychology, 52, 1-10.

Patrick, S., Sells, J. N., Giordano, F. G., \& Tollerud, T. R. (2007). Intimacy, differentiation, and personality variables as predictors of marital satisfaction. The Family Journal, 15(4), 359-367.

Pond, D.A., Ryle, A. \& Hamilton, M. (1963). Marriage and neurosis in a working class population. British Journal of Psychiatry, 109, 592-598.

Pritchett, R., Kemp, J., Wilson, P., Minnis, H., Bryce, G., \& Gillberg, C. (2011). Quick, simple measures of family relationships for use in clinical practice and research. A systematic review. Family Practice, 28, 172-187.

Quinton, D. Rutter, M., \& Liddle, C. (1984). Institutional rearing parenting difficulties and marital support. Psychological Medicine, 14, 107-124. 
Register, L., \& Henley, T. (1992). The phenomenology of intimacy. Journal of Social and Personal Relationships, 9, 467-481. Letöltve: 2011. 03. 17-én: spr.sagepub.com at VPI \& STATE UNIV LIBRARIES

Reis, H. T,. \& Shaver, P. (1988). Intimacy as an interpersonal process. In S. Duck (Ed.), Handbook of personal relationships (367-389). Chichester, England: Wiley \& Sons.

Rosseel, Y. (2012). Lavaan: An R package for structural equation modeling. Journal of Statistical Software, 48(2), 1-36. Letöltve: 2019. 04. 10-én: http:/ / www.jstatsoft.org/v48/ i02/

Ryle, A. (1966). A marital patterns test for use in psychiatric research. British Journal of Psychiatry, 123, 535-541.

Sherbourne, D.C., \& Stewart, A.L. (1991). The MOS Social Support Survey. Social Science and Medicine, 32, 705-714.

Simon, A. (1988). A Zung-féle Önértékelő Depresszió Skála (ÖDS) In: Szakács Ferenc (szerk.): Pszichodiagnosztikai vademecum I./1. (180-184). Budapest: Tankönyvkiadó

Simpson, J. A. (1990). Influence of attachment styles in romanitc relationships. Journal of Personality and Social Psychology, 39, 971-980.

Sipos, K., \& Sipos, M. (1978). The development and validation of the Hungarian form of the STAI. In: Spielberger CD, Diaz-Guerrerro (Szerk.). Cross-Cultural Anxiety 2. (51-61). Washington DC: Hemisphere

Snell, W.E., Jr., Schicke, M., \& Arbeiter, T. (2002). The Multidimensional Relationship Questionnaire: Psychological dispositions associated with intimate relations. W.E. Snell, Jr. (Ed.), New directions in the psychology of intimate relations: research and theory. Cape Girardeau, MO: Snell Publications

Spanier, G.B. (1976). Measuring dyadic adjustment: new scales for assessing the quality of marriage and similar diads, Journal of Marriage and the Family 38, 15-28.

Spielberger, C D., Gorsuch, R.L., \& Lushene, R.E. (1970). Manual for the State-Trait Anxiety Inventory. Palo Alto, CA: Consulting Psychologist Press

Sz. Makó, H., Bernáth, L., Szentiványi-Makó, N., Veszprémi, B., Vajda, D., \& Kiss, E.Cs. (2016). A MOS SSS - Társas támasz mérésére szolgáló kérdőív magyar változatának pszichometriai jellemzői. Alkalmazott Pszichológia, 16(3), 145-162.

Takács, Sz. (2012). Érzékenységvizsgálatok a statisztikai eljárásokban, Alkalmazott Matematikai Lapok, 29, 67-100.

Takács, Sz. (2016). Bevezetés a matematikai statisztikába, elmélet és gyakorlat. Budapest: Antarész Kiadó

Talmadge, L., \& Dabbs, J. (1990). Intimacy, conversational patterns, and concomitant cognitive/emotional processes in couples. Journal of Social and Clinical Psychology, 9, 473-488.

Tóth, I., Gervai, J. (1999). Szülői Bánásmód Kérdőív (H-PBI): A Parental Bonding Instrument (PBI) magyar változata. Magyar Pszichológiai Szemle, 4, 551-566.

Urbán, R. (1994). Az intimitásról. Magyar Pszichológiai Szemle, 50(1-2), 84-98.

Vargha, A. (2015). Matematikai statisztika. Budapest: Pólya Kiadó

Warring, E.M., \& Reddon, J.R. (1983). The measurement of intimacy in the marriage: The Waring Intimacy Questionnaire. Journal of Clinical Psychology, 39, 53-57.

Wilhelm, K., \& Parker, G. (1988). The development of a measure of intimate bonds. Psychological Medicine, 18(1), 225-234.

Wilhelm, K., \& Parker, G. (1990). Reliability of the parental bonding instrument and intimate bond measure scales. Australian and New Zealand Journal of Psychiatry, 24, 199-202.

Wilhelm, K., Brownhill, S., \& Boyce, P. (2000). Marital and family functioning: different measures and viewpoints. Social Psychiatry Epidemiology, 35, 358-365. 


\section{Köszönetnyilvánítás}

Ezúton szeretnénk köszönetet mondani a kérdőívet rendelkezésünkre bocsátó Kay Wilhelmnek és Gordon Parkernek, az IBM-Hu kérdőív fordításában nyújtott segítségért Gérecz Ágnesnek és Végh Fruzsinának, a kérdőívek kitöltésére időt és energiát fordító vállalkozó szellemú vizsgálati személyeknek, valamint az adatgyújtésben résztvevő múhelymunkát és szakdolgozatot készítő hallgatóknak.

\section{Szerzói munkamegosztás}

Hadházi Éva: kérdőív fordítása, vizsgálat és adatgyưjtés megtervezése, lebonyolítása, elméleti áttekintés, adatfeldolgozás, az eredmények értelmezése, bemutatása. Takács Szabolcs: adatfeldolgozás, statisztikai számítások, az eredmények értelmezése, bemutatása.

\section{Nyilatkozat érdekütközésról}

A szerzők ezúton kijelentik, hogy esetükben nem állnak fenn érdekütközések.

\section{Függelék}

\section{Az Intim Kötődés Mérése (IBM-HU) kérdőív}

Ez a kérdőív a közeli kapcsolatokban megjelenő attitúdök és viselkedések listáját tartalmazza. Kérem, ítélje meg, milyen attitúd és viselkedésmintát mutat mostanában a partnere Önnel szemben úgy, hogy minden tétel esetében a legmegfelelőbb rubrikába tesz egy pipát.

\begin{tabular}{|l|c|c|c|c|}
\hline & 3 & 2 & 1 & 0 \\
\cline { 2 - 5 } & $\begin{array}{c}\text { Tökélete- } \\
\text { sen igaz }\end{array}$ & $\begin{array}{c}\text { Többnyire } \\
\text { igaz }\end{array}$ & $\begin{array}{c}\text { Kismérték- } \\
\text { ben igaz }\end{array}$ & $\begin{array}{c}\text { Egyáltalán } \\
\text { nem igaz }\end{array}$ \\
\hline 1. Törődik velem. & & & & \\
\hline $\begin{array}{l}\text { 2. Egy vitában a saját oldalára } \\
\text { akar állítani. }\end{array}$ & & & & \\
\hline $\begin{array}{l}\text { 3. Pontosan tudni akarja, hol } \\
\text { vagyok és mit csinálok. }\end{array}$ & & & & \\
\hline 4. Jó társ. & & & & \\
\hline 5. Kimutatja felém az érzelmeit. & & & & \\
\hline $\begin{array}{l}\text { 6. Látszik, hogy megbántódik, } \\
\text { ha nem osztom a nézeteit. }\end{array}$ & & & & \\
\hline
\end{tabular}




\begin{tabular}{|c|c|c|c|c|}
\hline & 3 & 2 & 1 & 0 \\
\hline & $\begin{array}{l}\text { Tökélete- } \\
\text { sen igaz }\end{array}$ & $\begin{array}{l}\text { Többnyire } \\
\text { igaz }\end{array}$ & $\begin{array}{l}\text { Kismérték- } \\
\text { ben igaz }\end{array}$ & $\begin{array}{c}\text { Egyáltalán } \\
\text { nem igaz }\end{array}$ \\
\hline 7. Megpróbál megváltoztatni. & & & & \\
\hline 8. Erősen megbízik bennem. & & & & \\
\hline $\begin{array}{l}\text { 9. Apróbb dolgokban is } \\
\text { hajlamos megkritizálni engem. }\end{array}$ & & & & \\
\hline $\begin{array}{l}\text { 10. Megérti a gondjaimat és } \\
\text { problémáimat. }\end{array}$ & & & & \\
\hline 11. Szokott utasítgatni engem. & & & & \\
\hline $\begin{array}{l}\text { 12. Ragaszkodik ahhoz, hogy } \\
\text { mindent úgy csináljak, } \\
\text { ahogyan ó mondta. }\end{array}$ & & & & \\
\hline $\begin{array}{l}\text { 13. Testi dolgokban gyöngéd } \\
\text { és tapintatos. }\end{array}$ & & & & \\
\hline $\begin{array}{l}\text { 14. Érezteti, hogy szüksége van } \\
\text { rám. }\end{array}$ & & & & \\
\hline $\begin{array}{l}\text { 15. Kis dolgokban akar } \\
\text { megváltoztatni. }\end{array}$ & & & & \\
\hline 16. Nagyon szeret. & & & & \\
\hline 17. Uralkodni próbál felettem. & & & & \\
\hline 18. Jó vele lenni. & & & & \\
\hline $\begin{array}{l}\text { 19. Nagy dolgokban akar } \\
\text { megváltoztatni. }\end{array}$ & & & & \\
\hline $\begin{array}{l}\text { 20. Ellenőrizni akar mindent, } \\
\text { amit teszek. }\end{array}$ & & & & \\
\hline $\begin{array}{l}\text { 21. Kimutatja az elismerését, } \\
\text { bármit csinálok. }\end{array}$ & & & & \\
\hline $\begin{array}{l}\text { 22. Négyszemközt kritikus } \\
\text { velem. }\end{array}$ & & & & \\
\hline 23. Gyöngéd és kedves velem. & & & & \\
\hline $\begin{array}{l}\text { 24. Barátságos és meleg hangon } \\
\text { beszél hozzám. }\end{array}$ & & & & \\
\hline
\end{tabular}

Skálák kialakítása: az egyes tételeknél elért pontokat kell összegezni, fordított tétel nincs.

Gondoskodás skála: 1., 4., 5., 8., 10., 13., 14., 16., 18., 21., 23. és 24. tétel

Kontroll skála: 2., 3., 6., 7., 9., 11., 12., 15., 17., 19., 20. és 22. tétel 


\section{Presentation of psychometric characteristics of the Intimate Bond Measurement questionnaire (IBM-HU)}

Background: The Intimate Bond Measurement (IBM) questionnaire is suitable for determining and measuring the two main constructs of intimacy, the care and control dimensions, in international research, it is mainly used as a tool to measure intimacy in partnership. Aim: in our study we present the psychometric characteristics of the questionnaire on the Hungarian population. Method: 1318 persons (250 men, 1068 women; average age 34.77 years, $\mathrm{SD}=10.91$ years) filled in self-reporting questionnaires in a cross-sectional study, beside the demographic data: Intimate Bond Measurement, Relationship Assessment Scale, Experiences in Close Relationships - Relationship Structures, Parental Bonding Instrument, Trait Anxiety Inventory, Zung Self-Rating Depression Scale and The MOS Social Support Survey. Results: Due to the confirmatory and exploratory factor analysis, the same factor structure outlined as shown by international literature. The Cronbach's alpha values are high enough (Care Scale: 0.94; Control Scale: 0.91) and scales correlated negatively ( $\mathrm{r}=$ $-0.58, p<0,01)$. The degree of intimacy was independent of socio-demographic factors (gender, education, place of residence, income situation, marital status, presence and number of children). People who were self-reported to suffer from chronic illnesses and those who were treated for mental reasons were distinguished from the sine morbo group. And in the values of the care scale they were below those that did not have such characteristics, while the values of the control scale were significantly higher for those receiving treatment for psychological reasons. The correlation of intimacy with other factors was only considered where the correlation coefficient reached 0.3 . The relationship satisfaction showed strong, positive correlation with care, and negative with control. Care negatively while control is positively correlated with the scale of avoidance and anxiety of adult attachment with partner. From parental bonding, the paternal restriction arises in the group of those who are treated for mental problems: the more restrictive their father was, the less caring and the more controlling they find their partner. Depression and trait anxiety showed a negative correlation with care perception, although not everywhere reached the relevant level. The perception of control was only associated with depression and trait anxiety in patients with chronic disease. We found a positive correlation of all three dimensions of social support with care, and a consistent negative correlation with control, but their strength was quite variable. Conclusions: IBM-HU can be considered a reliable and valid measurement tool for the care and control dimensions of intimacy.

Keywords: intimacy, intimate bond measurement, IBM-HU, confirmatory and exploratory factor analysis, reliability, validity

A cikk a Creative Commons Attribution 4.0 International License (https:/ / creativecommons.org/ licenses/by/4.0/) feltételei szerint publikált Open Access közlemény, melynek szellemében a cikk bármilyen médiumban szabadon felhasználható, megosztható és újraközölhető, feltéve, hogy az eredeti szerző és a közlés helye, illetve a CC License linkje és az esetlegesen végrehajtott módosítások feltüntetésre kerülnek. (SID_1) 